FROM PATAÑJALI TO THE “GOSPEL OF SWEAT": YOGA'S REMARKABLE TRANSFORMATION FROM A SACRED MOVEMENT INTO A THRIVING

GLOBAL MARKET

\author{
Kamal Munir \\ Judge Business School \\ University of Cambridge \\ Cambridge, CB2 1AG \\ United Kingdom
}

Phone: +44 1223337054

Fax: +44 1223339701

Email: k.munir@jbs.cam.ac.uk

Shahzad (Shaz) Ansari

Judge Business School

University of Cambridge

Cambridge, CB2 1AG

United Kingdom

Phone: +44 1223768128

Fax: +44 1223339701

Email: s.ansari@jbs.cam.ac.uk

\author{
Deborah Brown \\ Department of Politics and International Studies \\ University of Cambridge \\ Cambridge \\ United Kingdom \\ Phone: +44 7545827661 \\ Email:dmb60@cam.ac.uk
}




\title{
FROM PATAÑJALI TO THE “GOSPEL OF SWEAT": YOGA'S REMARKABLE TRANSFORMATION FROM A SACRED MOVEMENT INTO A THRIVING GLOBAL MARKET
}

\begin{abstract}
Movements seeking to infuse markets with moral values often end up utilizing the market mechanism and support from mainstream actors to scale up, even if it comes at the cost of diluting their founding ethos. However, this process can be particularly challenging for movements that are explicitly opposed to using a market mechanism as a means of scaling up. Our analysis of yoga between 1975 and 2016 reveals how a counter-cultural movement fundamentally opposed to a capitalist market economy but seeking to grow can paradoxically become syncretic with markets. We show how, before such a movement can be commodified, it must be de-essentialized, a process that requires stripping away key aspects of its history, context, and religious commitments and transforming collective goals into individual ones. This process involves not only external entrepreneurs looking to mine the movement, but also movement leaders seeking wider enrollment of resource-rich actors to scale the movement up. We show how codes borrowed from parallel movements and templates borrowed from markets can be instrumental in driving such a movement's transformation. Through this "extreme" case of the yoga movement, we advance understandings of how movements can become syncretic with values and practices they fundamentally oppose.
\end{abstract}

Key words: Social movements, moral markets, commodification, commensuration, values, morality, yoga.

Acknowledgements:

We would like to offer our sincere thanks to our highly engaged and thoughtful Editor, Forrest Briscoe and three anonymous ASQ reviewers who offered us a wealth of insights to advance our thinking. We would also like to thank Diane-Laure Arjaliès, Stefan Arora-Jonsson, Grace Augustine, Santi Furnari, Patricia Hein, Lamia Irfan, Tom Lawrence, Mike Lounsbury, Zehra Munir, Woody Powell, Chiqui Ramirez, Madeleine Rauch, Davide Ravasi, Juliane Reinecke, Florian Überbacher, Marc Ventresca, Samsurin Welch, Andrea Wessendorf, and participants at ASA meeting 2015 in Chicago, AOM meeting 2018 in Chicago. OTREG meetings in Cambridge 2018-19, SCANCOR Stanford University Seminar, 2020. Kings College London seminar, 2018, Uppsala university seminar, 2016 and EM Lyon seminar, 2018 who provided us with constructive insights and suggestions. 
Yoga is derived from the Sanskrit word "Yuj" that means "to bind together," "to hold fast," "to yoke"...the purpose of all this is to unify the spirit, to do away with the dispersion and automatism that characterize profane consciousness. (Eliade, 2009: 5)

The physicality of yoga reminded me how to feel good in my body. Its meditative side made me feel good in my head. (Stiles, 2010: ix)

Studies at the intersection of social movements and markets (e.g., Carroll and Swaminathan, 2000; King and Pearce, 2010) have shown how the relationship between the two can be both contentious and confrontational, as well as collaborative and complementary. Movements try to infuse markets with morals, often by supplying cultural codes that contain a "values" dimension of the morally desirable and undesirable (Weber, Heinze, and DeSoucey, 2008); however, markets also permeate movements and influence them in important ways (Soule and King, 2015). As movements attempt to scale up by expanding their boundaries and harnessing the power of markets, they risk diluting their core values and ethos (Hiatt, Sine, and Tolbert, 2009; Lee, Hiatt, and Lounsbury, 2017). Recent research has identified various strategies for avoiding this fate and achieving the twin goals of scaling up and preserving the movement's authentic values (Hedburg and Lounsbury, forthcoming). However, as these movements seek change explicitly through the market, and do not fundamentally oppose a market system or an exchange infrastructure, they can still accommodate the mainstream market for scaling up, even if they try to avert the blunting of their radical edges.

Movements that explicitly oppose the idea of creating profit-driven markets around what they consider to be civic, social, and community-based responsibilities (Radin, 1996) cannot readily embrace markets as a means to scale up, even though markets provide a potent means to increase impact. These movements include, among others, streams of the environmental movement (Frank, Hironaka, and Schofer, 2000), anti-capitalist movements (Reinecke and Ansari, forthcoming) and religious and spiritual movements (Yue, Wang, and Yang, 2018; Rochas and King, 2018) that oppose the commodifying nature of a market and 
seek a radical transformation of society. Counter-cultural movements (Andretta, della Porta, and Saunders, 2019; Roszak, 1995) oppose not just specific aspects of markets, but the ideological underpinnings of market capitalism (Cini et al., 2017), which poses a more fundamental obstacle to accommodating the market mechanism as a means of scaling up. How is conflict with markets resolved in such movements?

Yoga is a particularly fertile empirical setting for investigating these dynamics. This ascetic, anti-market movement which started in India and arrived in earnest on American shores in 1893 came to be at the center of an $\$ 80$ billion global market in 2016, one-fifth of which was in the United States. This is remarkable because, inspired by Hindu philosophy (De Michelis, 2004), the yoga movement's central codes were meant to provide an antidote to the individualism and consumerism fostered by capitalism, aiming to free one from all worldly, material considerations (Vivekananda, 1947). Eventually, the movement was cleansed of its anti-materialist essence and "market-encumbering" religious constraints. A meditative and spiritual practice with the ultimate aims of self-diminution, ego transcendence, and union with the divine (Strauss, 2004) was transformed into a "certifiable," priceable, and user-friendly product with different proprietary versions promising a positive body image, fitness, and stress-relief that could be bought and sold in the market. Theoretically, this setting enables us to take a deeper look at how movements that oppose market capitalism itself can become implicated in it, and paradoxically even become syncretic with a market ethos. We use the term 'syncretic' to describe the infiltration of an ostensibly pure tradition by concepts, beliefs and meanings seen as belonging to other, incompatible, often conflicting traditions (Stewart and Shaw, 1994). Anti-market movements do not simply integrate or fuse with markets, but transform to become syncretic with them.

Our study enables us to make three contributions. First, in contrast to movements seeking change through the market, we show how movements opposed to a market economy 
but seeking to scale up need to be "de-essentialized" before their core practices can be commodified. De-essentialization refers to the untethering of a movement from its meaning and historical context. We identify three components in the de-essentialization process: (a) selective desacralization, or selectively stripping a movement of its market-fettering "baggage;" (b) individualization, or converting its collectivist ethos into an individualist one; and (c) decontextualization, or obscuring its historical context to make it marketable.

Second, we show how such movements are not simply "coopted” (Lounsbury, Ventresca and Hirsch, 2003), or appropriated by market actors, but syncretize with markets with the help of legitimizing support offered by movement leaders seeking wider enrollment and impact. Entrepreneurs and movement leaders become unlikely allies in this process. The latter provide discursive justification for entrepreneurs trying to forge new, easier-to-sell aspirations around the movement's core practices and facilitate commensuration to enable expansion. Our analysis shows movements and markets do not necessarily present mutually exclusive and irreconcilable worlds comprising the sacred and the profane. Instead, the syncretization of conflicting moralities in "connected lives" (Hitlin and Vaisey, 2013; Zelizer, 2012) suggests an interpenetrative relationship between movement actors who need markets to grow, and market actors who mine movements to create and expand markets.

Finally, we reveal how actors borrow and adapt codes from other intersecting and overlapping movements (Rao, Monin, and Durand, 2005) and fuse them with market templates to forge new markets and expand extant ones (Munir and Phillips, 2005). We shed light on how borrowing codes from overlapping versus non-overlapping movements might elicit different levels of resistance from within the movement. In doing this, we advance research on boundary spanning and spillovers (Meyer and Whittier, 1994; Wang, Piazza, and Soule, 2018), and offer a perspective that is not movement-centric (Crossley, 2015; Fligstein and McAdam, 2011; Walder, 2009) nor isolated from the larger context. 


\section{THEORETICAL MOTIVATIONS}

An increasing number of studies at the intersection of social movements and markets (e.g.,

Davis et al., 2008; King and Pearce, 2010) have shown how movements can coerce corporations into acting more responsibly (e.g., Davis et al., 2008 ). By increasing pressure on these actors, social movements seek to infuse markets and market actors with moral values, and/or create and legitimize alternative markets (Akemu, Whiteman, and Kennedy, 2016; Bartley, 2007; Briscoe and Gupta, 2016). These alternative markets often develop around cultural codes supplied by movements, as seen in the cases of grass fed beef (Weber, Heinze, and DeSoucey, 2008), soft drinks (Hiatt, Sine, and Tolbert, 2009), green products in banking (Almandoz, Lee, and Marquis, 2017), renewable energy (Sine, Haveman, and Tolbert, 2005; Vasi, 2011), and construction (York, Vedula, and Lenox, 2017). These codes are not accepted readily by markets, just as movements resist market actors' attempts to coopt them. This conflict between the consumerist, growth-oriented and profit-making ethos of markets and the moral values held by movement members becomes particularly palpable as movements engage with mainstream market actors in an attempt to grow and increase impact.

\section{The Movement-Market Tension and Cooptation}

The scaling up of moral movements can be a double-edged sword. On the one hand, movements need to maintain the purity of their moral ideas and restrict the entry of nonadherents who diminish the salience of moral values (Lee, Hiatt, and Lounsbury, 2017). On the other hand, without courting mainstream participation for scaling and impact, they risk marginalization, irrelevance, and even dissipation. Thus, in many cases, tension arises between the twin goals of reaching the widest possible audience, for which markets provide a potent mechanism, and preserving movement authenticity. In other words, movements can easily find themselves in situations where they can either remain confined to niche markets or dilute their core values by embracing mainstream markets. 
Often described as movement cooptation (e.g., Lounsbury, Ventresca, and Hirsch, 2003) this dynamic has been observed in many studies. Lee, Hiatt, and Lounsbury (2017), for instance, showed how the scaling up of the organic food movement allowed the entry of more commercially minded members, and certification became product- instead of producer-based, resulting in a significant compromise of the original intent behind the movement. In a similar vein, Reinecke and Ansari (2015) showed how the Fair-Trade movement seeking to reform unfair agricultural trading practices in the developing world had to adopt market mechanisms of standardization and certification as a necessary evil to satisfy buyers' demand for credible guarantees of ethically sourced products. Similarly, McInerney's (2014) study of "Circuit Riders"- a group of activists who mobilized IT professionals to work pro bono for nonprofits so that they could transcend the digital divide — showed how the movement was “captured" by entrepreneurs as it tried to scale up by expanding its boundaries. Finally, Michelon, Rodrigue and Trevisan (2020) showed how the shareholder activism movement was marketized through the infusion of profit-oriented motivations that recast corporate social responsibility as risk management.

While seen across a broad range of contexts, movements are not necessarily co-opted in their entirety. In fact, recent research has identified various strategies for movements to balance "ideological purity" and pragmatic "selling out" (Whittier, 2002: 298). For instance, Hedberg and Lounsbury, in a forthcoming paper, point out how movements can initially decouple their core values and practices to attract mainstream participation, and then recouple them after scaling up. However, while all these aforementioned movements have elements that oppose aspects of particular markets and seek to infuse them with moral values that clash with commercialization imperatives, for the most part they accept the idea of a capitalist market economy. As such, they can still accommodate the market mechanism for scaling up, even if it potentially threatens their authenticity. 
In movements that seek to reform society as a whole, however, the conflicting ethos of the movement and the commodifying aspects of markets present a stark contrast. That is, when movements embody codes that are a particularly "bad match" with contemporary markets (Fourcade, 2012: 1059), their values are fundamentally at odds with commodification that requires the production of at least four interrelated and cumulative qualities: objectification to disentwine products from the personhood of subjects; fungibility to make products exchangeable and interchangeable; commensurability to allow products to be scaled or ranked in comparison to others; and monetization to allow product evaluation in monetary terms (Radin, 1996).

These movements with anti-materialist philosophical trappings would seem incommensurable with a market ethos that enables categorization and smooth exchanges (Espeland and Stevens, 1998; Khaire and Wadhwani, 2010), and unamenable to commodification, or the creation of products with specific price tags (Montemaggi, 2013). This is because they often seek to challenge an individualized social order produced by markets, emphasizing instead the concepts of humanism, community, sharing, sacrifice, meditation, mysticism, or spirituality. Examples include anti-capitalist movements seeking a radical transformation of society (Cini et al., 2017), such as the decroissance (degrowth) movement to promote a post-growth society (Muraca, 2013), and the Occupy movement rallying around "Capitalism is Crisis" (Reinecke and Ansari, 2020), or counter-cultural movements such as the New Age movement (NAM) (Heelas, 1996), and American Buddhism (Rojas and King, 2018). These movements promote alternative ways of living with new forms of spiritual experience, and detachment from materialism to liberate people from the stress, suffering, and angst caused by the frantic pace of Western society (Laraña, Johnston, and Gusfield, 1994). Given their opposition to the dominant mechanistic and 
materialist orientations of consumerist Western society, these movements cannot readily accommodate markets as a mechanism for scalability.

On the face of it, movements posing fundamental obstacles to market formation should make unappealing targets for entrepreneurs seeking to mine them for economic value. However, even such movements are not immune to market influence in contemporary society (Carette and King, 2005). Consider the corporatization of the Buddhism-derived mindfulness movement (sometimes called McMindfulness) by Silicon Valley companies that have adopted mindfulness programs in their attempt to improve worker performance and create “corporate athletes" (Purser, 2019). In a study titled, "Cutting the Buddha's Body to Fit the Neoliberal Suit, " Cohen (2017) described how Buddhism had been increasingly secularized, psychologized, medicalized, and adapted to the Western individualistic ethos, where angst and stress is explained as an individual pathology of the mind to be "cured" through meditation, deflecting attention away from its cultural, institutional, and socio-economic sources. Similarly, Ellingson (2013: 70-71) described the transformation of American Protestantism in U.S. megachurches by organizers who have refashioned piety and "literally steered religious organizations to behaving like for-profit businesses as they build brand identities and services in pursuit of a market share." These examples show that even countercultural movements fundamentally opposed to materialism can be "extracted" from their socio-historical contexts to walk hand in hand with markets.

To sum up, how the opposing ethos of movements and markets are reconciled needs more elaboration. Due to their opposition to the very institution of a market, counter-cultural movements seeking to liberate their members from the consumerist and materialist tendencies engendered by markets serve as ideal sites to study this phenomenon. How these movements become syncretic with markets is what we explore here. 


\section{METHODS}

\section{Research Context}

To answer our research question, we studied how the ascetic, spiritual and anti-consumerist yoga movement transformed into a $\$ 80$ billion global market. We chose this empirical context because it represents an extreme case (Eisenhardt, 1989) of a movement which was not confined to reforming a market but was opposed to the very institution of markets. As Pratt, Rockmann, and Kaufmann (2006) pointed out, issues of theoretical interest tend to be more visible in extreme cases.

Yoga is an ancient South Asian philosophy with the ultimate goal of Samadhi, a state of enlightenment achieved through the observance of strict moral and ethical standards and meditation practices (De Michelis, 2004). The eight limbs of yoga, according to the Yoga Sutras written by Patañjali (a revered name in yoga) in around 2 BCE, comprise yamas (abstinences), niyamas (observances), asana (yoga postures), pranayama (breath control), pratyahara (withdrawal of the senses), dharana (concentration), dhyana (meditation), and Samadhi (absorption). They require the yogi to live by moral codes that govern every aspect of life, such as truthfulness, non-violence, repudiation of material desires, cleanliness, satisfaction with what one has, austerity, self-study, oneness with the object of meditation, and bliss. Notably, postural practice constitutes only one of the eight limbs; the aim is to strengthen the body sufficiently so that one may sit in meditation for long periods.

Given yoga's long and rich history, a detailed account of how it developed would require much more space. In this paper, we begin our study period in 1975 for two reasons. First, an overwhelming majority of changes that led to a thriving yoga market occurred after the 1980s. Second, one of our key sources, Yoga Journal, is only available from 1975. In the widely cited Yoga in America study (Yoga Journal and Yoga Alliance 2016), 61\% of respondents indicated that they obtained information about yoga from Yoga Journal, making 
it the primary source of information for yoga teachers and trainees. In 2016, Yoga Journal had close to two million readers and more than 14 million page views, making it the most influential and respected yoga magazine by far.

We found Yoga Journal to be an unparalleled catalogue of the debates and turning points that marked yoga's gradual acceptance and entrenchment in the United States. Rather than simply mirroring trends in the field, it also provided intellectual leadership. Yoga's leading influencers and personalities authored articles that directly tackled difficult questions, not only providing rich descriptions of how particular practices, movements, and interests seemed to be changing yoga, but also engaging in detailed debates on these changes, often in special issues.

At the same time, thanks to its consistent intellectual leadership, Yoga Journal was a key movement leader. It was formed, by its own account, to bring coherence and coordination to the gradually growing movement, and help it grow. In its very first issue, for instance, it declared that it aimed to mobilize the 'yoga community' to bring yoga to the masses. Its role was particularly interesting because of the bold positions it consistently took on different questions e.g., doing a special issue on women gurus at a time when they were almost invisible in the larger movement. Indeed, the most trenchant critics of the decontextualization of yoga, such as the Hindu American Foundation, blamed the Yoga Journal above all for the mainstreaming of yoga. Whereas initially the Yoga Journal resisted the marketization of yoga, later it became a cheerleader for yoga's increasing commodification.

When Yoga Journal was launched in 1975, yoga was essentially a philosophy that prescribed a particular code of life aimed at ultimate liberation or enlightenment. Over the years, it became more physical, but as early issues of Yoga Journal illustrate, it was still very much about how life was to be lived. By 2005, however, it had been transformed beyond all recognition. Yoga's strict moral and ethical codes as well as its aspiration to attain 
enlightenment had largely been discarded as the physical practice dominated. Yoga became a workout which promised to give practitioners a slender, toned body, sexual prowess, youthfulness, a calm mind, and relief from everyday stress. Gone were all the other cardinal principles on which yoga had been based, and which promised to enable practitioners to attain self-realization.

It was fascinating to observe how Yoga Journal itself transformed. Initially, it served as the flagship journal of a movement, staking out new positions on issues ranging from women's leadership roles to the compatibility of yogic philosophy and capitalism. Anticapitalist and anti-consumerist articles written by highly qualified individuals ultimately were supplanted by articles championing the new version of yoga, along with many of its consumerist values and ambitions. The demographic shift in yoga practice was reflected in Yoga Journal's readership, which was nearly $80 \%$ women in 2015. Its two million readers came from 36 million practitioners of yoga in the U.S. alone. The Yoga in America Study (Yoga Journal and Yoga Alliance 2016) found another 44 million aspiring practitioners.

Yoga went from a movement underpinned by a religious and meditative philosophy that took years to learn, to one that advocated weekend courses to become a yoga instructor. Yoga postures were copyrighted and franchised. The representation of yoga in popular discourse, and the values associated with it, also underwent transformation. Its image went from pictures of yoga gurus meditating in a loin cloth to athletic women in acrobatic poses that represented a blend of ballet, gymnastics, and yoga. Many of these women emerged as the new gurus serving as role models for urban middle-class women the world over.

This rise reflected the increasing push that came from commercial actors now championing the practice of yoga. Retailers specializing in yoga wear (e.g., Lululemon, Sweaty Betty) burst onto the scene in the 2000s. Likewise, established brands like Nike and 
Adidas produced yoga lines. Nike even launched Kyoto, a yoga/dance shoe (Melillo, 2003), even though yoga is traditionally practiced barefoot.

\section{Data Collection}

Secondary data. To develop an understanding of the movement, we began by performing a survey of the academic literature on yoga. This involved reading 12 academic books on yoga and its history, and 12 non-academic books by prominent yoga teachers and studios. We also read nine books on issues related to yoga (e.g., leisure, spirituality, fitness, etc.), as well as training manuals. In addition to reviewing survey research on changing attitudes towards spirituality, we scoured copies of leading yoga magazines (i.e., Yoga Journal, Yoga Today, Yoga and Health) published between 1975 and 2016. Among these, Yoga Journal served as the principal source, for reasons described above. Third, using the online database Factiva, we searched all major U.S. papers from 1980 (when significant coverage began) to 2016 for major mentions of the term yoga, excluding articles with high similarity.

Primary data. Whereas much of our analysis was based on data gleaned from publications, we also collected primary data to understand firsthand how yoga was enacted, understood, and commercialized. This involved fieldwork in the form of participant observation and interviews with participants and instructors. One of the authors was a participant observer in 408 yoga classes, a 200-hour Yoga Alliance certified teacher-training program and six fieldconfiguring events.

Finally, we interviewed 31 individuals involved in yoga practice as studio owners, teachers, practitioners, or entrepreneurs, including executives of yoga brands. The interviewees ranged in age from their early 20 s to mid-60s and were predominantly white and middle class (largely representative of the yoga movement). All interviews, with one exception, were conducted face-to-face and ranged from 45 minutes to 2.5 hours. Audio recordings of the interviews were transcribed and then input into NVivo and coded. We also 
conducted an additional 36 informal interviews which we did not audio record but documented in field notes. See Tables 1 and 2 for our data sources and key insights derived.

\section{Data Analysis}

We analyzed the data in three stages. First, we coded 240 issues of Yoga Journal published between 1975 and 2016. We not only coded the covers for what they signaled (e.g., focus on body versus philosophy, sexuality, community versus individual) but also the content of articles and advertisements and the aspirations they reflected. Moreover, we tracked changes in editors along with editors' own profiles, to the extent such information was available.

Our content analysis enabled us to track yoga's changing representations from a movement based on a collectivist, religious, ascetic philosophy that shunned market relations to an individual enterprise focused on body image and stress relief. It also enabled us to track the sources of the different frames that were being utilized to describe yoga (e.g., various cultural codes borrowed from the New Age Movement (NAM), health, and fitness movements). Finally, we focused on resistance to these changes - specifically, how the issues, loci, targets, and proponents of resistance changed over time.

Coding in NVivo helped us track the changes in yoga over 40 years. Table 3 depicts our coding scheme and aggregate theoretical dimensions, while Figure 1 shows how various themes became prominent or faded with time. Similarly, Figure 2 shows how the covers of Yoga Journal evolved with time.

----Insert Table 3 and Figures 1 and 2 here -----

Second, we performed a discourse analysis of data collected from major U.S. newspapers. Factiva yielded over 60,000 articles with mentions of yoga. We ran searches for major keywords associated with yoga, ranging from "spirituality" to "fitness" and "body." The analysis helped us trace how certain associations strengthened while others weakened, 
and revealed the key actors that mined these new associations. Relative to all articles about yoga, Figure 3 depicts the proportion of articles containing these keywords published in major U.S. newspapers between 1980 and 2016. In Figure 4, we show how yoga was represented as a way to develop better abs or a "yoga butt," not only on the cover of Yoga Journal but in ads for clothing or yoga classes. This became important once the yoga market developed, as the discourse expanded beyond Yoga Journal into mainstream spaces.

-------Insert Figures 3 and 4 here-------

Third, we reviewed our interview transcripts and field notes. Although our coding of magazines and newspapers enabled us to identify the various influences on and changes in yoga, these data enabled us to witness their enactment and identify the influence, for example, of celebrities, yoga entrepreneurs, and yoga brands in creating a market.

\section{YOGA'S TRANSFORMATION AND THE CREATION OF A NEW MARKET}

Here, we describe how yoga, which started as an amorphous and fragmented counter-cultural movement, transformed into a thriving market. Before describing its transformation, however, we describe the state of yoga in 1975, the beginning of our data collection period. Early Beginnings. In 1975, we found yoga to be a loosely organized movement without a central authority capable of speaking for the movement, clear hierarchies, or a narrowly defined membership. It was sustained by the arrival of yoga gurus from India who found rich, well-connected patrons in the United States. During nearly 80 years in the United States, the yoga movement had spread through a variety of means, including yoga instruction studios, residential centers, publications, lectures, and conferences. In 1975, a group of committed yoga teachers in California launched Yoga Journal with the explicit intention of coordinating and growing the yoga movement in America. The journal began by defining what the yoga movement was all about. Coding of journal issues published between 1975 and 1980 clearly 
revealed five defining traits. Table 4 depicts representative headlines and quotes from Yoga Journal, while Figure 1 shows how their salience increased or decreased over time.

\section{--------Table 4 About Here-----}

First, yoga was characterized by strong religious sensibilities. Between 1975 and 1980, for instance, we found that, on average, three articles in each issue invoked God and religion in connection with yoga. Although yoga's connection with Hinduism was not based on a rigid set of orthodox beliefs, it was nonetheless so deeply established that many leading yoga personalities questioned the ability of humans to truly understand the world using only a secular lens. Second, the yoga movement centered on an ancient moral and ethical philosophy. The inaugural 1975 issue of Yoga Journal defined yoga as "one of the six classical schools of Indian philosophy." Third, prior to the 1990s, the movement only partially emphasized postural yoga. The aim was enlightenment, and articles frequently proclaimed that practicing yoga postures without relating them to yoga's deeper moral and ethical philosophy could increase tension. Fourth, the dominant discourse in the yoga movement tended to be collectivist, with an interest in larger social, political, and economic issues. Throughout the 1970s and 1980s, Yoga Journal frequently published articles on how a different social, political, and economic reality was possible, taking clear stances on a variety of these issues. Finally, the yoga movement clearly opposed capitalist relations of production and consumerism. A number of early articles emphasized that a market-based economy was inconsistent with yoga teachings of devotion and the renunciation of materialism. For example, in early articles about physical ailments, the focus was invariably on how the Western medical industry prioritized profits over patients and cure over prevention.

We now describe how these characteristics, as well as the Yoga Journal's position on them, changed over time. Although we present our analytical description in chronological order, yoga's transformation was not linear, nor were all agents' first transformation attempts 
successful. An important aspect was the borrowing of codes and templates from other movements and markets over the years. This process was driven primarily by intersections between the yoga movement and three other movements that also were markets. See Table 5 for these borrowed codes and templates and how they became part of the yoga movement.

-----Table 5 About Here-----

\section{Parallel Movements Influencing Yoga's Transformation}

As we scoured the Yoga Journal archives, we found evidence of new cultural codes and market templates being adopted by members of the yoga movement and yoga entrepreneurs. The New Age Movement (1960s-1980s). Yoga's transformation was influenced significantly by its intersection with the NAM, which represented a departure from the political counter-cultural movements of the time. The $\mathrm{NAM}^{1}$ situated itself outside the confines of traditional religions, emphasizing spirituality as something "free, private, optional and according to one's own needs and understanding" (Pickering, 1975: 6). Over time, the NAM transformed perceptions of the world's spiritual traditions, which became viewed as possible choices in a "religious consumer supermarket" (York, 2001: 361).

Because the NAM was essentially an educated, middle-class phenomenon (Heelas, 1996) considerable overlaps existed with the yoga movement, as evidenced by surveys (e.g., Morth, 1989) and interactions between adherents of the two movements in articles published in Yoga Journal. New Age Journal ads frequently appeared in Yoga Journal, and vice versa (Appendix A), and many leading figures of the NAM were influential in yoga as well.

Nevertheless, the contradiction between the NAM's individualism and yoga's collective sensibilities surfaced at times. Yoga leaders occasionally criticized the NAM yet avoided open confrontation. The editorial in the November 1991 issue, for instance, stated:

\footnotetext{
${ }^{1}$ https://www.pewresearch.org/fact-tank/2017/09/06/more-americans-now-say-theyre-spiritual-but-notreligious/
} 
"In recent years a certain idea has gained currency in New Age circles: 'You create your own reality'... this notion seems to be a bastardization of Eastern teachings about karma and the nature of consciousness" (Bodian, 1991: 4). However, thanks to considerable overlaps and the adoption of codes from the NAM (Table 5), New Age ideas went on to profoundly influence the yoga movement.

The Holistic Health Movement (1970s-1980s). In addition to the NAM, the 1970s saw the rise of the holistic health movement (HHM), which drew on the increasing focus on individual health and fitness and advocated that a healthy life was one in harmony with nature. The movement criticized Western medicine for confining itself to curing diseases rather than preventing them, and for ignoring holistic aspects of health and healing. The movement was a mixed bag of alternative medicine philosophies that included aspects of humanistic medicine, parapsychology, folk medicine, herbalism, nutritional therapies, homeopathy, meditation, and yoga (Goldner, 2001; Salmon and Berliner, 1979, 1980).

The movement had clear overlaps with both the NAM and yoga movements. The NAM emphasized wellness, self-actualization, and tranquility (York, 2001), and included therapeutic techniques, such as reflexology or shiatsu, that were assimilated into the HHM (Danforth, 1989). Similarly, yoga was adopted for both its meditative and postural qualities. The yoga movement borrowed various codes from the HHM (Table 5) as health continued to become an increasingly salient theme throughout the 1980s and 1990s (Figure 1).

The Fitness Movement (1980s onward). The fitness movement, which gathered strength in the 1980s and spawned a sizable market, focused on both physical health and bodily aesthetics (Green, 1986; Stern, 2009). Physical exercise was tethered to work through phrases such as working out and attached to institutionalized education via fitness classes (Brabazon, 2006). This focus on health improvement has a long history in American culture (Conrad, 1994). The "Muscular Christianity" movement promoted physical exercise as a way to 
develop a healthy, religious, and morally righteous lifestyle (Putney, 2001) through the YMCA and affiliated gymnasiums. Although the movement attracted many followers, especially among the middle classes, participation in fitness was not as widespread as it is today (Andreasson and Johansson, 2014). Prior to the 1970s, relatively few Americans exercised regularly. In 1960, only 24 percent of Americans claimed to exercise regularly; however, by 1987, results of a Gallup poll showed that the proportion of regular exercisers had climbed to 69 percent (Gurin and Harris, 1987).

Far from being holistic, a major accomplishment of the fitness movement was to create an ideal type for each body part, with body builders working on different muscle groups using different equipment and techniques. Corporations were quick to notice the profit potential in this trend, and numerous new enterprises emerged, including fitness apparel companies (e.g., Nike, Adidas) and gym chains which marketed fitness as a form of identity that could be worn on the body.

The body quickly became an evaluative marker (Roy, 2008; Turner, 1991) used by individuals to judge themselves and others. Buoyed by the feminist movement, women joined the fitness movement in droves, comprising 60-65\% of members (Stern, 2009). Until 2000, there was little direct overlap between the yoga and fitness movements. Later, entrepreneurs liberally borrowed codes from fitness to redefine yoga. Despite vocal resistance from core members (e.g., Yoga Journal readers), movement leaders actively borrowed codes from the fitness movement (Table 5), which had rapidly turned into a sizeable market.

\section{The Transformation of Yoga: De-essentialization and Commodification}

Yoga's transformation was essentially enabled by the movement's desire to expand in America, the influence of other movements, entrepreneurs seeking to capitalize on the movement, a reluctant embrace of corporate sponsorships to meet resource needs, and wider 
socio-economic changes. Below, we describe the complex interplay of these factors. Our analysis led to the coding scheme in Table 3 that guides our account.

The transformation process involved two major components: a shift in yoga's meaning (i.e., de-essentialization), and the development of a market around it (i.e., commodification). The de-essentialization of yoga involved selective desacralization, individualization, and decontextualization, whereas the commodification of yoga involved forging new aspirations, commensuration, and discursive justification. Collectively, they enabled the syncretization of yoga, or its integration with concepts and practices initially opposed by the movement.

De-essentialization. As Figure 1 depicts, mentions of Hinduism had completely disappeared from Yoga Journal by 2000. This selective desacralization process involved three distinct elements. First, during the 1980s, cultural codes borrowed from the NAM emphasizing a whatever works spirituality rather than a religious code were central to eliminating religion from the yoga discourse. As Table 5 shows, cultural codes such as spirituality, invocation of the age of Aquarius, and individual choice became part of the yoga movement during the 1970s and 1980s. This process was enabled by the partial membership overlap between the two movements. Several leaders at the nexus of the two movements used the codes provided by the NAM to gradually replace the imprisoning and canonical religious with the ecumenical and more inclusive spiritual when it came to the dominant discourse surrounding yoga. Noted Yoga columnist Phil Catalfo (1981: 31) wrote in Yoga Journal that it would be better to use the word "spirituality" rather than "religion" to avoid "credos or congregations." Similarly, influential author and yogi Alice Rankin (1980: 8), hailed as an "oracle of the New Age" by Yoga Journal, proclaimed:

Yoga is not a religion. I believe everyone should be able to engage in whatever religious practices they like, without fear that yoga will threaten their beliefs in any way. ... In the 1980s, I feel that yoga will come out from under this imprisoning cloud of religious affiliation. 
The gradual omission of religious codes from Yoga Journal was lamented by many movement members, perhaps most visibly by the Hindu American Foundation (HAF). Over several decades, the HAF consistently petitioned the journal's editors, who were perceived to be the most influential voices in the movement, not to separate yoga from its Hindu roots. The HAF claims their suspicions were confirmed when, upon calling Yoga Journal, they were told, "Yeah, they [the editors] probably avoid it [religious references]. Hinduism does, like, you know, have a lot of baggage."2

By the 2000s, Yoga Journal had considerably changed its position, acknowledging the need to "Americanize" yoga to expand the movement. As a result, any religious associations were cast aside (Figure 1). Clearly, many core members were unhappy with how yoga was being recast. Many letters to the journal protested the decoupling of yoga from its roots. The HAF was appalled at the lengths to which the journal was prepared to go to obscure yoga's Hindu roots. In an open letter to Yoga Journal, ${ }^{3}$ HAF spokesperson Suhag Shukla wrote:

After reading this month's articles, "Eat Like a Yogi," "The Essence of Life" and "Everyday Ecstasy," and admiring the prominently printed "Oms" throughout the magazine, I couldn't help but wonder, "How many ways are there to avoid the word 'Hindu'?'

Notably, not all religious symbols or practices were discarded by entrepreneurs who had been at the forefront of desacralizing yoga. Despite going against the wishes of many movement members by portraying yoga as a secular practice, yoga entrepreneurs, studio owners, and Yoga Journal retained a few of yoga's original elements, including references to Hindu deities (Ganesh), rituals such as chanting of mantras (Om), and the use of Sanskrit to provide a sense of authenticity. The HAF noticed "the mantra of the month, the sacred Hindu symbol, Om, sprinkled throughout the magazine" without "any reference to Hinduism."4

\footnotetext{
${ }^{2}$ https://www.hinduismtoday.com/blogs-news/hindu-press-international/hindu-american-foundation-launches-take-back-yoga--campaign/9928.html

${ }^{3}$ https://www.hinduamerican.org/wp-content/uploads/2020/03/YogaJournalLetter.pdf

${ }^{4}$ http://www.hinduwisdom.info/Yoga_and_Hindu_Philosophy.htm
} 
Yoga Journal's gradual shift was noticed by its founders too. One of the founding editors Judith Lasater (2010) wrote:

I feel sad because it seems that Yoga Journal has become just another voice for the status quo and not for elevating us to the higher values of yoga: spiritual integration, compassion and selfless service. My request is that Yoga Journal doesn't run ads with photos that exploit the sexuality of young women in order to sell products or more magazines.

Our observation of yoga practice revealed that classes often began with the Hindu greeting "Namaste," even when the participants did not know what it meant. The symbol Om was used copiously in otherwise highly secular studios and splashed across yoga wear. A British yoga instructor we spoke to changed her name from Susan to Saraswati to appear more "authentic." Many of our interviewees confessed that without some elements, symbols, and hallmarks of the original practice, it would be difficult to maintain the distinction between yoga and regular fitness classes. Sanskrit terms for the various postures served no other purpose than to symbolically connect yoga to its mystical tradition and retain a vague spirituality to differentiate it from other fitness classes. Religious symbols and artifacts were retained to enrich Western consumerism with Eastern spirituality and mysticism.

We also noticed the individualization of yoga over time. Throughout the 1970s and 1980s, most articles in Yoga Journal dealt with wider socio-economic, ethical and ecological issues, and were openly critical of consumerism, corporations, and markets. The March 1976 issue, for instance, included an article called "Yogeconomics: Part I \& II," about the type of economic and taxation system that would be compatible with a yogic philosophy. Similarly, a feature article in the February 1978 issue talked about the food industry and how greed was playing havoc with the food chain. These themes were also reflected in various talks being given to members of the U.S. yoga movement.

As Figure 1 shows, the number of Yoga Journal articles taking an anti-capitalist stance fell dramatically in the 1990s, dwindling to zero in 1998. The yoga movement no longer 
remained wedded to political ideals. Although pressure from entrepreneurs looking to mine the movement was obviously a key factor, this shift was facilitated by the influence of the NAM and HHM (Table 5). The idea that yoga practitioners should choose their own paths rather than rather than conform to a collective code was borrowed from the NAM. Similarly, the HHM shifted responsibility for the realization of health from the collective to the individual level. Entrepreneurs built on these developments. Tara Stiles, a leading yoga entrepreneur and instructor based in New York, famously claimed: "there are no rules in life and you need to follow your intuition and what makes you feel good" (as cited in Kubicek, 2014). She prided herself on making yoga accessible and inventing her own user-friendly version of the practice. She explained: "People need yoga, not another religious leader... I was never invited to the party anyway - so I started my own.",

This new sensibility was reflected in an announcement by CorePower Yoga, a leading chain of yoga studios: "Our role is to guide students to make yoga practice their own and their intention personal — each student is encouraged to embark on their own spiritual journey."6

The individualization of yoga signaled a shift in the movement from collective to individual aspirations that was clearly visible on Yoga Journal covers. Throughout the 1980s and early 1990s, covers depicted yoga gurus, communities, or abstract artwork with relevant social themes. However, by the mid-1990s, these had given way to aspirational covers focused on attractive bodies. The aspiration was to work on the self to make it more desirable and stress-free rather than to become part of any larger movement. Figure 4 shows contrasting covers of Yoga Journal over time.

\footnotetext{
${ }^{5}$ https://www.nytimes.com/2011/01/23/nyregion/23stretch.html

${ }^{6} \mathrm{http}: / / \mathrm{www} . c o r e p o w e r y o g a . c o m$
} 
As shown in Figure 1, yoga also underwent a gradual decontextualization. From the 1970s through the 1990s, debate within the yoga movement raged on the extent to which the practice should remained aligned with its roots. Purists argued that yoga was a holistic philosophy and needed to remain whole to be effective. Dissecting yoga into pieces, adopting some aspects but rejecting others, was heavily criticized. For instance, the cover feature of the July 1977 issue of Yoga Journal stated: "Yoga is a holistic system and must be understood in its totality. The danger we are subject to falling into is picking up on two or three yogic concepts and isolating them from the totality of yoga" (Paull, 1977: 5).

Most yoga practitioners believed that this totality could only come from years of practice, absorbing not just the postural elements, but everything else from the guru, who was not just a teacher, but someone who dispelled darkness, having experienced inner awakening. Noted guru Sharath Jois explained that gurus are careful not to alter teachings: " The parampara (lineage) should go as it is - as it was - from your guru and his guru's guru. It needs to be rooted in something real and not just fancies that are created in the moment." Yoga's holistic philosophy and religious origins had always been intertwined. However, this changed as the movement expanded. A Founding Editor of Yoga Journal explained:

Whereas earlier we had to borrow everything from India, and rely on their immense knowledge, by the 1990s the lineage was being broken. I realized this when I taught a workshop to Zen students. They would chant the names of their lineage all the way from Buddha every morning. That is the way to keep the practice close to its original philosophy. Now, many people doing yoga have absolutely no idea where this whole thing came from. Some even think it was invented in California in the 1980s.

Two factors were instrumental in the Americanization of yoga. First, well-known yogis admitted that given a different context, it was difficult to transmit the whole of yoga as it had evolved in India to Western practitioners. A 1990 issue of Yoga Journal clearly acknowledged that in order to spread yoga in America, it would have to be Americanized.

\footnotetext{
${ }^{7}$ https://www.hafsite.org/media/pr/yoga-hindu-origins
} 
Second, and relatedly, the U.S. yoga movement was influenced by its American context. Entrepreneurs justified their franchising and copyrighting of yoga through the trope of being American. In an interview on CBS News in 2010, Bikram Chaudhry, the most high-profile yoga teacher in America during the 1990s and 2000s, summarized his approach: "I built an empire. Why not? ... [It's the] American way: make Bikram yoga, copyright, trademark, franchising, patent” (Brezinski, 2005).

Once begun, the Americanization of yoga (i.e., McYoga) was hard to stop. Yoga Journal's Founding Editor explained: "In the 1970s, we had learned yoga from Hindus. We took it all on. Over time, yoga transformed; it adapted to American norms and culture. We adapted yoga. It is so American, doing things our own way." She acknowledged, however, that very quickly things spun out of control, with yoga losing its essence. As she put it, "the genie was out of the bottle."

Beyond obscuring yoga's philosophical and Hindu roots, yoga was decontextualized through mockery of its rigid constraints. For example, the manifesto of a yoga studio, Fierce Grace, proclaimed "We won't Om you" and assured readers of its website that "this is not an Indian Secret Mystery Club." Yoga clothing lines frequently referenced in the social media sphere used phrases such as: "Namaste, bitches" and "Warning: Too much yoga can make you hot." "In a yoga class that we attended, the instructor said, "Move it so you don't end up with a belly like Buddha," nodding toward a statue of Buddha in a corner of the studio.

Commodification. The commodification of yoga was facilitated by forging new aspirations for the yoga movement. In 1975, the essence of yoga was very much spiritual and philosophical, with the yoga movement fully conscious of the fact that the sole purpose of postural yoga (asana) was to strengthen the body for long periods of meditation. During the

\footnotetext{
${ }^{8}$ In Sanskrit, "Namaste" is a reverential greeting meaning "I bow to you." These are just two examples of slogans printed on yoga clothing and retweeted by yoga studios. Other examples include "They say yoga leads to better sex," and "Yoga: My favorite pretend way to work out." (http://www.lookhuman.com/design/44023warning-too-much-yoga-can-make-you-hot)
} 
movement's early stages, Pattabhi Jois, a world-renowned yoga guru explained: “using it [yoga] for physical practice is no good, of no use- just a lot of sweating, pushing, and heavy breathing for nothing. The spiritual aspect, which is beyond the physical, is the purpose of yoga" (Medin, 2014: p. 8). Indeed, even when discussing postures, the aspiration was always spiritual (e.g., to awaken kundalini, or the primal energy stored at the base of the spine).

Our analysis of major newspapers and journals reveals clear links to health, including mental health/stress and physical therapy. This association with health was never a core aspect of the yoga movement, as explained to us by a Founding Editor of Yoga Journal, Judith Lasater: "In 1976, I was asked to teach a yoga class to people with back pain. It was a radical concept! We just didn’t think of yoga as a remedy for physical ailments!” However, given the significant overlaps between the holistic health and yoga movements, postural yoga (asana) was increasingly understood in terms of its health benefits. Through the 1980s and 1990s, for example, Yoga Journal published several special issues on health. Whereas the initial focus was indeed on holistic health, gradually it became more interventionist. For instance, the January/February 1990 issue discussed at length how some well-known yoga poses could improve your health. Likewise, contemporary yoga instructors confided in us that they had begun marketing yoga to corporations as a way to ensure a healthy, "stressfree" workforce. Other claims framed yoga as a way to decrease blood pressure, anxiety, and depression, improve self-efficacy, and combat post-traumatic stress disorder, drug addiction, and substance abuse (Khalsa et al., 2012).

By the turn of the century, Yoga Journal had undergone a significant shift. As depicted in Figure 1, the themes in a typical issue had changed dramatically. Early editors were committed members of the yoga movement and adopted a purist approach to content. However, in 1998, a wealthy yoga practitioner bought the journal, and editors began to embrace broader content that reflected new fitness-related aspirations. The fitness movement 
created an ideal type for each body part, and the holistic practice of yoga was distilled to techniques to get "super abs," or a "yoga body." Yoga Journal played a key role in linking yoga with fitness, which was entirely absent from the yoga movement in the 1970s and 1980s. In Yoga Journal's May 2000 issue, the editor stated:

Two worlds - the traditional yoga community and the fitness industry - have rarely mingled, until recently. Hoping to bridge the gap between the two communities and focus on their shared ideal of well-being, Yoga Journal is partnering with IDEA Health and Fitness to host Yoga Connection, a conference in Anaheim, CA. The conference is intended to provide fitness instructors with a firm grounding in yoga philosophy and techniques, and to introduce yoga teachers to the special needs of health clubs.

The slight reticence reflected in the quote above indicates that Yoga Journal was aware that readers might not support a whole-hearted embrace of the fitness culture. Indeed, many readers did voice stringent objections to what they perceived as a stark deviation from yoga's principles. Nevertheless, the turn towards fitness continued and in 2001, "strong abs" appeared on the cover of a Yoga Journal issue, marking a clear shift towards a new yoga aimed squarely at developing particular body parts. Yoga was now increasingly associated with a "better-looking butt."

By the 2000s, Yoga Journal was using body image and celebrities to sell yoga, reflecting increased alignment between its editorial position and market actors. Celebrities in search of spiritual fulfillment widely promoted yoga (Jain, 2014), and yoga enthusiast and supermodel Christy Turlington became Yoga Journal's Editor-at-Large. A yoga teacher with over 40 years of experience told us how newcomers began to seek out her class in search of Sting's abs or Madonna's biceps.

Because new practitioners were motivated by body image, it was no surprise to see yoga gurus undergoing makeovers, too (Figure 5). A prominent new guru was Tara Stiles, a former model and yoga instructor who developed a brand for fellow yoga instructors and attracted a following of over 140,000 people on Instagram. Her lithe and well-toned body was used to market the physical benefits of yoga, with no reference to the spiritual benefits. 
Figure 5 shows Tara Stiles's ad for W Hotels, a Vogue magazine cover, and a Lululemon ad for yoga wear, all of which are far cries from what yoga originally represented ${ }^{9}$. Corporate actors strengthened this trend significantly. In 2013, Lululemon, worth about $\$ 11$ billion at the time, began hiring athletes to work in its stores rather than yoga practitioners; founder Chip Wilson explained that athletes better fit the brand's profile to attract clientele.

-----Figure 5 about here----

A commensuration process also contributed to the commodification of yoga. As yoga attracted more practitioners, it was clear that a few gurus would not be sufficient to meet demand. It became apparent that scaling up to include newcomers who were looking for yoga bodies would require a constant supply of certified instructors who visibly embodied the characteristics that practitioners desired (see Figure 5) — an idea that was considered blasphemous within the movement. Alice Rankin (1978: 45), an influential figure in the movement, wrote: "there have never been diplomas and certification of yoga gurus, nor in reality can there ever be." Yoga, she wrote, was learned through a close relationship between disciple and guru, and instructors who had not been immersed in "this ancient philosophy" for years were doing a "disservice to their students" and the philosophy.

Even when sexual harassment scandals involving gurus surfaced in the 1980s, movement leaders remained ambivalent, as depicted in a Yoga Journal editorial:

What can it possibly mean for a student to sue her guru in a court of law ... It's absurd-like bringing God to trial for making a mess of the universe! Who's going to judge the case? Justice So-and-so from the Eighth District Court? What authority does he have? The legalistic and spiritual world views are totally incompatible! (Bodian, 1985: 4)

However, as gyms began to offer yoga courses and demand for instructors increased, such concerns were swept aside as standardized teacher training became a major source of profit.

\footnotetext{
${ }^{9}$ This review of Lululemon founder Chip Wilson's book provides a glimpse into how yoga was reinvented by the brand: https://www.vox.com/the-goods/2018/10/22/18010410/chip-wilson-lululemon-athleisure-book
} 
New training programs could be completed in mere days. In 2000, a Yoga Journal columnist narrated his experience in an instructor certification course:

In just one weekend, I became a certified yoga teacher. ... The formula was actually quite simple. We didn't learn about the spiritual aspects of the practice at all. Nor did we study Sanskrit terms, yoga history, philosophy or ethics. Basically, the entire operation was a cliff-notes preparation designed to ready us for the health club members all across America who are clamouring for yoga. (Barrett, 2000: 83)

Concurrently, several entrepreneurs created new, proprietary categories of yoga. Foremost among them was Bikram Choudhury, who pioneered the use of intellectual property rights and franchising to develop a global business (Fish, 2014). The product was a patented sequence consisting of 26 postures taught during a 90 -minute class at a temperature of $105^{\circ} \mathrm{F}\left(40^{\circ} \mathrm{C}\right)$. Bikram also developed a two-month teacher training program that certified 350-440 Bikram instructors at a time (Bikram Yoga, 2015).

These efforts comprised a two-pronged shift in the practice of yoga in the West, resulting in a flood of yoga-related patenting activity. By May 2016, there were 4,175 trademarks registered in the United States that included the word "yoga" (U.S. Patent Office, 2016). Second, yoga studios gradually adopted a corporate form dominated by chains such as Fierce Grace, Yoga Works, and CorePower Yoga. A chain's representative noted: “the principle was to honor the tradition of yoga and create the sense that you were entering a sacred space. We wanted to dispel the illusion about who can practice yoga, because it is for everyone-hence, 'everyone triyoga'” (Sattin and Woodhall, 2013). CorePower's co-founder described the chain as the "Starbucks of Yoga;" with over 200 locations in 23 U.S. states and Washington, DC, the "fitness empire" churns out thousands of "certified" yoga instructors per year (Hines, 2019).

Resistance to this dramatic marketization of yoga came from the now outnumbered core movement members, the HAF, and even the Indian government, which created a database of 1,300 yoga postures believed to be documented in ancient Indian texts (Sinha, 
2011). The hope was that the database would function as a reference point for patent offices all over the world. In 2014, the Indian government even appointed a minister for yoga to promote what India framed as our system and reclaim yoga's Hindu roots (Alexander, 2014).

The commodification of yoga could not be carried out solely by entrepreneurs or corporations; it required discursive justification from within the movement, provided primarily by Yoga Journal, which increasingly required corporate sponsorships. After two decades of gradual change, by the late 1990s, the journal was actively steering its readers towards embracing capitalist consumerism. In the May 2000 issue, for instance, it cited the views of prominent author Carol Connare, who opined: "maybe the pairing of yoga and marketing is an uneasy partnership, but it is probably unavoidable in America" (Connare, 2000: 23). She quoted a leading yoga figure Alan Finger as saying:

As long as yoga images are used by the media tastefully and in the true spirit of the practice, I don't see a conflict. Billboards all over NY show people meditating; it's the age of spirituality. If not through a commercial context, how else do you reach the masses with this important message?

In 1998, after two decades of being led by individuals who were yogis first and editors later, and tired of perpetually struggling to raise funds, Yoga Journal hired an "entrepreneurial editor with a successful record of repositioning and relaunching magazines and building brand extensions." 10 This marked a decisive shift in the journal's editorial policy and in the types of subscribers it wanted to attract.

Soon thereafter, in early 2000, Yoga Journal bestowed "Karma Credits” on Banana Republic for launching a line of yoga apparel. This unleashed a torrent of adverse feedback from readers who accused Yoga Journal of selling out by endorsing exploitative Western apparel firms. In the May 2000 issue, a yoga teacher wrote to the editor, noting that because yoga taught that "we were all one," she was "not separate from a 14 year-old girl in Saipan

\footnotetext{
${ }^{10}$ Editor's Linkedin profile.
} 
who sat on a sewing machine all day." The editor's response revealed Yoga Journal's new conciliatory position: "Instead of condemning Banana Republic, isn't embracing them the yogic thing to do? We can hold both the 14-year-old girl in Saipan and Banana Republic in our hearts and it does not need to be a contradiction."

In many instances, Yoga Journal played a more passive role, allowing commercial enterprise to distort yoga's history to create a new narrative that fit better with existing notions of beauty or fitness. In the November 1999 issue, the editor of Yoga Journal wrote:

A couple of years ago, when I had just returned to Yoga Journal after six months of traveling to ashrams and holy sites in India, I got a call from a writer for Mirabella magazine who was researching a fashion spread on exercise wear. "I was wondering" she said, "what is the traditional outfit for doing yoga?" I thought of the naked yogis I had seen on the banks of the Ganges, their skin smeared with ashes from the cremation pyre to remind themselves of the body's impermanence, their foreheads painted with the insignia of Shiva, the god of destruction. I couldn't resist. "Well, traditionally, you would carry a trident and cover your body with the ashes of the dead," I told her. There was a long pause, during which I could practically hear her thinking, "This will never fly with the Beauty Editor." Finally, I took pity on her. "But alternatively," I told her, "leotards and tights will work just fine."

The journal took a similar position with regard to instructor certification. Although the journal initially questioned the appropriateness of outsiders regulating or standardizing yoga, its position became more conciliatory over time, with many leading yoga instructors themselves training new cohorts of instructors in programs of increasingly shorter duration.

Had it not been for this crucial role played by Yoga Journal, the transformation might not have proceeded as it did. As it was, by 2010, yoga had become highly compatible, or syncretic, with the commercial world around it. It was being used to sell not only apparel and other yoga related commodities, but products as diverse as cars (Nissan), spirits (Absolut Vodka) and computers (Lenovo's yoga laptop). A new form of yogic investing was supposed to help clients "integrate yoga and money" (Pavia, 2013), and advertising agencies described yoga as: "a reliable medium through which the advertiser can communicate with the Special 
K demographic" (Lane, 2003). A sizable market had emerged around a movement that began with no such aspirations and was diametrically opposed to the principles of a market society.

Yoga's transformation cannot be understood apart from the social and economic currents of change in American society at the time, as depicted in Pew research surveys. ${ }^{11}$ To some degree, yoga entrepreneurs could capitalize on the rise of individualism and the increasing turn to the secular, as well as the ecumenical and non-denominational spiritual rather than the religious, as exemplified by the NAM's attempts to appropriate spirituality (York, 2001). A gradual depoliticization unfolded at the national level after the 1960s, which picked up strength after the fall of the Berlin wall in 1989. Major counter-cultural movements had emerged in America in the 1960s and 1970s_-youth and student movements, the sexual liberation movement, and the hippie movement, to mention a few-to break out of the constraints imposed by the capitalist rationalization and bureaucratization of society. Rearticulating yoga to underscore its utility as a panacea for physical and mental wellbeing expanded and proliferated its utility to consumers. In this sense, the yoga movement's syncretization benefited from the rise of a market society (Fourcade and Healy, 2007) in which consumerist culture was not only accepted, but valorized and even glamorized, a tendency that was always anathema to traditional yogis. Ritzer (2000) calls this the McDonaldization of society, where efficiency and standardization shunted aside alternative movements and initiatives. While yoga entrepreneurs capitalized on these larger societal shifts, members of the yoga movement also fueled them by borrowing and blending codes from movements such as holistic health (Goldner, 2001) that had also become incorporated into markets through the assimilation of their alternative practices and ideologies.

\footnotetext{
${ }^{11}$ https://www.pewresearch.org/fact-tank/2018/08/29/religious-typology-overview/
} 


\section{SYNCRETIZATION OF COUNTER-CULTURAL MOVEMENTS AND MARKETS}

While at their core, most movements hold notions of values such as fairness and justice that go beyond what is achievable through the market mechanism, counter-cultural movements reach further by opposing the very idea of markets and a materialist existence. The sweeping nature of their aspirations makes them a fertile setting to study how the conflict between the ethos of movements and the ethos of markets may be reconciled. Such reconciliation is not inevitable, and several factors influence the courses movements take. For instance, as the case of yoga shows, entrepreneurs looking to mine a movement for value will find it difficult to succeed all by themselves. Changing a core aspect of the movement, and/or transforming a sacred practice into a commodity is likely to be met with resistance and lead to a crisis of legitimacy. Our findings inform a model which depicts how counter-cultural movements become syncretic with markets (Figure 6). To guide readers through the figure, we have put markers $(a, b, c \ldots)$

\section{-----Insert Figure 6 here-----}

As Figure 6 shows, the process begins as a movement undergoes changes when new codes are borrowed from overlapping movements by members and leaders (a). These codes serve as valuable resources to de-essentialize the movement. Because these codes emanate from local movements, their borrowing inevitably means that the focal movement assumes a local color (e.g., the Americanization of yoga). At the same time, movement leaders' evangelical desire to grow the movement requires accommodating members who are less committed to the movement's original ideals (b). This puts pressure on leaders to distance the movement from sacred or non-negotiable codes, allow more individual choice (i.e., veer away from collective goals), and obscure the movement's history.

De-essentialization involves de-emphasizing political, social, or religious aspects of a movement and opening central practices to new constructions and representations that broaden their appeal (Bekerman, Zembylas and McGlynn, 2009; Boucher, 2006; Yi and Silver, 2015). 
In other words, de-essentialization deracinates key practices from the very movement that infuses them with an essence. In our case, de-essentialization inverted the meaning of yoga, stripping it of its core codes and eventually separating the practice from the movement.

According to our model, de-essentialization proceeds in three inter-related ways: selective desacralization, individualization, and decontextualization. Desacralization involves attempts by key movement leaders to strip any non-negotiable, sacred meaning from core practices. An idea, phenomenon, or space (e.g., human life or the Dome of the Rock in Jerusalem), practice (e.g., burying the dead) or object (e.g., a human organ) is sacred when it is revered, transcends everyday life, and evokes passions and strong feelings (Durkheim, 1915). Whereas yoga's initial adopters in the West (i.e., the educated elite) recognized and embraced them, yoga's sacred Hindu roots proved to be an obstacle to the movement's growth. Desacralization is selective because some resemblance to the original entity must be retained (Binkley and Littler, 2011; Eliade, 1959). Selective desacralization thus allows a simultaneous nod towards the sacred while turning away from it, not seeking to validate or rigidly re-inscribe the traditional, but rather retaining some of its hallmarks and cultural cachet for trade. We argue that selective desacralization is at play when moral markets for life insurance and funeral services (Zelizer, 1979), human organs (Anteby, 2010; Healy, 2004), or human eggs and sperm (Almeling, 2007) are established.

De-essentialization also involves individualization. To varying degrees, movements are premised on shared notions of a better collective future, with communitarian and collective purposes lying at their cores. Discourses shared by movement members often require them to abide by a certain code of conduct to attain their goals, which can impede the commodification of the movement's central practices. Individualization involves attempts by movement leaders to shed any collectivist values that lie at the core of the movement. For example, vegetarianism began as a reformist reaction to industrialism's encroachment into everyday life and to promote 
social causes such as temperance. Later, it became individualized as a lifestyle, where people adopt vegetarian diets to cure or assuage health problems and consume an increasing variety of animal-free natural foods (Maurer, 2002).

Finally, de-essentialization requires decontextualization, which involves untethering a movement's core practices from their moral or historical context, which may clash with a consumerist society. Decontextualization has occurred over time in several social movements, ranging from microfinance (Armendariz and Szafarz, 2011) to Circuit Riders (McInerney, 2014). In our case, the decontextualization of yoga has been so successful that it is common to come across practitioners who are largely unaware of its Hindu roots or underlying collectivist philosophy. Excluding a movement's history from discourses and mocking the rigid constraints associated with the core philosophy are effective decontextualization techniques. For instance, capoeira, a form of Afro-Brazilian martial arts developed by slaves in colonial Brazil to prepare for uprisings against their masters, was decontextualized by removing troublesome racial references to Afro-Brazilian identity while retaining Brazilian music, and subsequently promoting the practice as an effective fitness activity (Robitaille, 2014).

De-essentialization does not occur on its own but is facilitated by the borrowing of codes from outside the movement by entrepreneurs and movement leaders (Weber, Heinze, and DeSoucey, 2008) (c). The borrowing of codes is easier when overlaps exist across movements, e.g., between yoga and the NAM and HHM, or between the vegetarian movement and the animal rights and health movements (Maurer, 2002). When little overlaps exist between movements, entrepreneurs and movement leaders must expend significant effort to bridge movements, as in the case of yoga and fitness.

In the latter case, as one would expect, there is bound to be resistance from within a movement to such shifts, just as there is to entrepreneurs seeking to monetize a movement under guises that are vastly different from the movement's original ideals (d). In yoga's case, 
the entry of businesses (e.g., Banana Republic) into the movement was not welcomed by members. Just as standards organizations seek to moderate the conflict between newcomers and core members, as in Lee, Hiatt, and Lounsbury's (2017) study of organic food, movement leaders play a role in overcoming such resistance (Figure 6, arrow f). Yoga Journal, for instance, played a central role in defending and justifying businesses and their own persistent deviations from yoga's core message. Gradually, new adherents were joining a movement that was no longer about seeking enlightenment, but about building the perfect body and alleviating stress caused by hyper-productive lives. A core group of disillusioned members remained, but the overall movement was engulfed by a booming market.

De-essentialization paves the way for commodification (e), defined as transforming things, ideas, or people into commodities or objects of exchange (Appadurai, 2005; Radin, 1996). Commodification assigns economic value to something that is seemingly beyond valuation and ought not be treated as a tradable commodity (Marx, 1867; Zelizer, 2005). Commodification is largely engineered by entrepreneurs seeking to generate economic value from an expanding movement and facilitated by movement leaders seeking to propagate their message and extend a practice to a wider audience. This process comprises at least three components. First, for a movement incompatible with markets, cultural codes from outside the movement must be adopted to forge new aspirations. Movements are aimed at bringing about large-scale change in the social order, directly through social action or indirectly through shifts in individual behavior. In some cases, markets might be able to contribute to the accomplishment of such goals. In many others, however, including in the case of yoga, abstract goals such as enlightenment or emancipation may not lend themselves directly to the commodification of core practices. Indeed, yoga's goals of achieving oneness, liberation, or ultimate enlightenment were not only abstract and demanding, but also hard to observe or measure. Fitness, on the other hand, was observable and in line with ideal body image types 
prevalent in the 1990s and 2000s.

Second, commodification requires commensuration, or transforming different aspects of a movement's core practice into a measurable, tangible, and seemingly achievable form, and measuring them by applying a common standardized metric (Espeland and Stevens, 1998). Through commensuration, the practice is made proprietary and scalable, and is divided into categories or types and certified. This process is essential for a competitive market to exist though the creation of categories, as seen in the construction of a marketable category and a coherent and comparable system of valuation for traditional Indian art (Khaire and Wadhwani, 2010). To accomplish this, templates are borrowed from parallel markets. In the case of yoga, Bikram Chaudhry borrowed the McDonald's franchising model, and prepared thousands of certified instructors to teach in those franchises.

Codes from other movements broaden a movement's remit to attract new members, and market templates enable it to be scaled up. Again, this is only possible with the help of discursive justification by movement leaders that create a foothold for commodification (f). Commodification necessarily requires making important changes to how the practice is made accessible to potential practitioners. However, entrepreneurs, who stand to gain the most from commodification, may not be accepted as legitimate actors, and their attempts to buy and sell a practice at the heart of an ascetic movement might be rebuffed by movement members. In such cases, entrepreneurs require the support of movement insiders to endorse these crucial shifts. In the case of yoga, corporate actors met with resistance initially, but this resistance gradually faded as the movement's intellectual leadership at Yoga Journal recognized that corporate advertisements were necessary to drive the movement's expansion. This was akin to Chasin's (2001) observation of the gay rights movement, where he noted how funding from several large firms fundamentally altered the movement's trajectory.

The mechanisms described above enable a movement to become syncretic with ideas it 
previously opposed (Leopold, 2001). In our case, these mechanisms reconciled the underlying philosophies of yoga and markets to form what would have once seemed like an unlikely kinship. Syncretization is visible in a number of other settings, including the environmental movement, which has come to embrace the market it had previously vilified for degrading the environment through what has been described as eco-entrepreneurship (Mars and Lounsbury, 2009). Similarly, shareholder activists and advocates of socially responsible investing have spurred a new market that melds social and environmental concerns with financial profit (King and Gish, 2015). Our model shows the interactive and complex relationships through which both movement outsiders and insiders exercise agency to make syncretization possible.

\section{DISCUSSION}

Movements that are opposed to markets - rather than those simply trying to extend or change them-offer fertile ground for studying how certain movements can reconcile with opposing value systems. The yoga movement, and its subsequent implication in a thriving market offers such an empirical site. Our analysis of this transformation allows us to make at least three contributions to existing research on the resolution of tension between the opposing ethos of counter-cultural movements and markets. First, we show how commodification is enabled by a process of de-essentialization. Second, we show how and where movement leaders exercise agency in commodifying the core practices of the movement, and finally, we demonstrate how the borrowing of codes and templates across parallel movements and markets is central to the twin processes of de-essentialization and commodification.

\section{De-essentializing a Movement}

We argue that movements seeking the radical transformation of a market economy and capitalist structures (Cini et al., 2017) need to be de-essentialized before they can be commodified. De-essentialization comprises three components: selective desacralization, individualization, and decontextualization. 
By appealing to different value systems and orders of worth, selective desacralization can increase market appeal by removing the market-encumbering aspects of a movement while retaining a few sacred symbols to maintain an aura of authenticity that facilitates differentiation and allows price premiums. In our case, the movement was not commodified in its original form; entrepreneurs did not attempt to sell Patañjali or ancient Hindu practices requiring decades of dedication and sacrifice. Nor did they completely strip yoga of religious symbolism. Rather, as is the case for Christmas celebrations in a Dubai luxury mall, or a trendy Buddha bar franchise, yoga was only selectively desacralized, invoking a modicum of Eastern mysticism even in its Westernized incarnation. This is akin to how the spiritual aspects of mindfulness are selectively retained, omitted, or altered (Purser and Milillo, 2015) in corporate employee development programs. Mindfulness has become a "technology of the self” informed by biomedical models of stress and wellbeing to increase productivity.

Selective desacralization not only increases market appeal but also challenges the classical dichotomy between the sacred and the profane in the moral market narrative. It highlights how essentialist interpretations of sacred versus profane and authentic versus inauthentic can prevent us from understanding how these polarities are negotiated and reconciled (Anteby, 2010; Dioun, 2018). Weber (1930) explained how the Protestant work ethic could be compatible with capitalism, resulting in the concept of Protestant prosperity. Consider how biotechnology spans this dichotomy, where bio expresses sacred life, and technology suggests the commodified. While the commercialization of life in the form of gene therapy and DNA engineering is highly contested, biotechnology lies at the frontiers of medical research and practice (Schultz, 1997). Similarly, Peifer et al. (2020) showed how patents were once viewed as a manifestation of capitalism's exploitative aspects that privatized a historically public good, but later came to be seen as "civilizing," because they enhance economic growth and more quickly bring about cures to lifesaving diseases. 
Selective desaclarization highlights that what is held sacred can prove to be both a form of baggage as well as a source of value creation. This especially holds where attempts to blend religious movements with economic value are made. Some religious organizations (e.g., megachurches) seek wider appeal by making religion "entertaining" and building brand identities (Ellingson, 2013). Similarly, local governments in China have attempted to create economic value from sacred Buddhist temples by promoting them to tourists without the need to follow demanding Buddhist rituals (Yue, Wang, and Yang, 2018) and pilgrimages to Israel have been transformed into appealing tourist packages (Shoval, 2000). Moreover, a religious event, Christmas, has become a global consumption festival, even in non-Christian contexts (Hirschmann and LaBarbera, 1989) but with a symbolic nod to religious history. Religious movements initially opposed to a market ethos have come to spawn new commercial offerings by stripping them of cumbersome regimens that may constrain wider adoption.

Movements opposed to markets may also become syncretic with them through individualization, which detaches a movement from its collectivist aspirations. The yoga philosophy to renounce material possessions and shun consumerism reflects collectivism, with an interest in wholesale changes in broader social, political, and economic issues. This philosophy is inconsistent with market principles, where freedom of choice is an enveloping framework of individual autonomy and self-expression (Giddens, 1991; Van Stekelenburg, Roggeband, and Klandermans, 2013). The reframing of angst, stress and burnout as individual pathologies to be managed avoids a direct confrontation with their socio-economic causes, such as a high-pressure work culture, and the underlying economic disparities and structural inequalities. Individualization freed yoga from the burden of such collectivist and communitarian ideals and practitioners became motivated by personal rather than collective goals. A similar change was seen in the vegetarian movement, where many members are 
motivated by personal lifestyle goals rather than by the movement's original political demands and aspirations for socio-economic change (Maurer, 2002).

Finally, decontextualization untethers a movement from its foundational underpinnings, thereby enabling it to expand to new contexts. For example, decoupling yoga from its religious foundations enabled it to expand to the fitness context. Likewise, the mindfulness movement had to be untethered from its original ethos to render it a corporate-friendly practice centered around health and performance perks. To become a profit center in the fashion industry, punk clothing had to be decoupled from the original ethos of the rebellious punk movement, whereby a subjugated lower class resisted the establishment through anticonventional means of self-expression (Santos and Avery, 2016). Whereas punk's founding members used handmade clothing to subvert commercial fashion, punk aesthetic today is bereft of its founding ethos, representing the very antithesis of the original philosophy.

Interestingly, a movement opposed to a market ethos, when syncretized, may paradoxically enable an even more diverse set of potential market domains to emerge, as it furnishes a wider repertoire of meanings (Pontikes, 2012). While new forms of value around yoga as sporty, sexy, and cosmopolitan are radically different from the original moral and religious intents of yoga, they nevertheless have gained worth and widespread appeal in a changing context with shifting criteria for social and moral evaluation and have enabled a variety of markets to emerge and thrive. While something is lost in translation, something new may also be gained in the fusion between seemingly disparate counter-culture and contemporary culture.

\section{Where Does Agency Lie in Commodification?}

Our analysis also provides insights into how commodification is made possible with the help of movement leaders. Commodification has been described as capitalism in "cell-form" (Marx, 1867). In this sense, it lies at the very heart of the tension we outlined between the 
ethos of a movement and the ethos of a market. However, delineating the tension between the two does not mean that we treat them as a binary in terms of values, or view marketization as problematic in and of itself. Markets have been seen both as moral (Hirschman, 1982) and amoral (Sandel, 2012; Walzer, 1983). From a sociological perspective, there exist different and often competing moralities that are historically and socially contingent, and are negotiated and contested among diverse actors from different arenas (Hitlin and Vaisey, 2013; Schiller-Merkens and Balsiger, 2019). For example, some have argued that yoga has facilitated the "Easternization of America," whereas others contend that markets have facilitated the "Westernization of yoga" (Brown and Leledaki, 2010). However, as Reich (2014: 1584) noted, how this happens and to what extent does not "arise out of thin air." Even the supposedly inexorable force of neoliberalism requires a helping hand. Agency exercised by movement leaders, members, and entrepreneurs is instrumental in this process.

We highlight three ways in which agency is exercised on both sides of the movementmarket divide: forging new aspirations, commensuration, and discursive justification. In contrast to an indelible tendency of markets to colonize every social practice or exchange, a movement may forge new aspirations to expand to other contexts in order to attract new members, which may require embracing market principles. Similarly, entrepreneurs, with the help of movement leaders, can establish links with other movements to both create new markets and expand existing ones. Initially, yoga postures were meant to enhance the ability to meditate rather than develop a fit body. However, once yoga was bridged with fitness, new possibilities emerged, with yoga eventually becoming associated with an attractive, lithe body and a clean, disciplined lifestyle followed by people who were "in control." At this point, yoga could be used to sell anything from an electric car to a pair of jeans.

The forging of new aspirations can be observed across several movements. For instance, in the organic food movement, the California Certified Organic Farmers' desire to 
"grow now and fix things later" (Lee, Hiatt, and Lounsbury, 2017: 456) enabled the entry of commercial producers seeking to weaken the definitions of organic to facilitate wider participation at the industrial level. And, in Fair Trade, the desire to expand the number of beneficiaries justified engagement with commercial farmers even if against the movement's founding principle to only work with small-holder farmers (Reinecke and Ansari, 2015). Similarly, in the microfinance movement, the Nobel Laureate founder of Grameen Bank, Yunus (2011), who described new for-profit microlenders as loan sharks, found himself sowing the seeds for microfinance's transformation by welcoming major corporate banks into the space. Microfinance's original goal, poverty alleviation, was transformed into financial inclusion, allowing for-profit microlenders to sell financial products to the poor (Bateman, 2011). Also, the environmental movement, which has lost part of its sacred "save the earth" ethos after insiders allowed the entry of entrepreneurs who harvested the movement for the creation of an ever-broadening range of innovative green products and services (e.g., York, Vedula, and Lenox, 2017). Movements may use commercialization as a "mobilizing technology" (Edwards and McCarthy, 2004) to resonate with a broader pool of supporters, but may end up admitting members looking for commercial opportunities whose values are misaligned with the movement (Lee, Ramus, and Vaccaro, 2018). A desire to grow may thus "double back" to influence movements in unintended ways.

The second point we make concerns commensuration. It has been established that commensuration speeds up both the production and appropriation of cultural forms (Khaire and Wadhwani, 2010; Simmel, 1978). The resulting depersonalization is critical to the functioning of a rational, bureaucratic, capitalist system (Weber, 1930). However, as Espeland and Stevens (1998: 315) pointed out, “commensuration warrants more sustained and systematic treatment." Consider how the Open Access (OA) movement sought to create a “knowledge commons" (Suber, 2007; Thananusak and Ansari, 2019) and revolutionize 
scholarly communication by removing permission barriers (copyrights and licensing). Mainstream publishers accommodated this radical movement against proprietary models by modifying the OA model through an author-pay system and make it commensurate with their extant business models. Apart from the payment structure, "gold" OA journals now operate in a similar way to subscription-based journals. In our case, the transformation of yoga underlines a crucial aspect of commensuration: Where does the legitimacy to commensurate the previously incommensurable (e.g., Zelizer, 2005) come from?

This brings us to our final point that commodification requires discursive justification from movement insiders to be legitimate. The replacement of the guru-disciple relationship with a system of thousands of yoga instructors who were certified in mere weeks or even days with little if any grounding in the original ethos of yoga required legitimation from within the movement. Driven by the desire to grow, movement leaders found themselves discursively justifying entrepreneurial strategies to their members. Over time Islamic finance has come to include derivative products but only once Islamic scholars in the vanguard of the Islamic finance movement discursively justified these products as being consistent with Islamic teachings (Gümüsay, Smets, and Morris, 2019).

Whereas others have highlighted how entrepreneurs try to legitimate their morally contentious work by downplaying commercial objectives (Anteby, 2010; Quinn, 2008; Yue, Wang, and Yang, 2018), we suggest that syncretization also involves depicting clashing moral values as seamlessly unified with commercial offerings. Such unification itself is a form of yoga, the Sanskrit word for yoke, meaning "union," "binding," or "joining together" to transcend Cartesian dualities (e.g., mind and body) and be at one with the universe (Herriott, Schmidt-Wilk, and Heaton, 2009). Ironically, yoga became "one" with neo-liberal consumerism, which it was meant to subvert. Yoga Journal's awarding of Karma Credits to 
Banana Republic and then defending it by suggesting that yoga teaches us to embrace both the little girl stitching clothes and the brand itself is illustrative in this regard.

While commodification is often seen as a quintessential sell-out of movements by market actors, it is difficult to carry out without support from within the movement. Our three sub-mechanisms of commodification suggest an interactive and interpenetrative relationship between movements and markets whereby markets are leveraged for social transformation and movements are enrolled to create new markets.

\section{Borrowing Codes from Parallel Movements and Markets}

The famous French author Victor Hugo (1896) noted, "phenomena intersect; to see but one is to see nothing." Our analysis shows that social movements must not be seen as standalone phenomena isolated from the reality and history of other movements and mobilizations (Fominaya and Cox, 2013). We suggest that constructing a market from a movement antithetical to market principles requires invoking cultural codes and templates that may not be available within the movement itself. These may need to be borrowed and blended from other intersecting movements, as well as from markets. In many social movement studies, broader "institutional and cultural factors tend to be treated as background conditions rather than as important explanatory factors" (de Bakker et al., 2013: 580). Their role in providing "a repertoire of capacities" (Swidler, 1986: 282) to actors for fashioning new patterns of activity and forging new linkages is thus underemphasized. Our analysis suggests the need to move beyond a movement centric focus (Fligstein and McAdam, 2011; Walder, 2009) to consider how overlaps with different movements may be a critical determinant of a movement's trajectory.

We therefore do not view social movements as self-contained (Meyer and Whittier, 1994) or isolated from the broader environments in which they are embedded (Calhoun, 2012; de Bakker et al., 2013). Instead, we offer a perspective that frames movements as 
overlapping and intersecting with members as cross-pollinators of beliefs and practices, thereby expanding a movement's reach. While boundary-spanning among movements is recognized (Wang, Piazza, and Soule, 2018), we highlight how the degree of overlap between a focal movement and intersecting movements may shape the level of resistance from within the focal movement. We suggest the need to study contemporaneous and historical crossovers between social movements such as the anti-globalization and Occupy movements, and to focus on movement ecologies rather than on social movements in isolation.

\section{Summary}

Overall, our findings contribute to research on how movements can become syncretic even with radically conflicting ideas and practices. We have highlighted how the deessentialization and commodification of such movements occur and how these processes require agency from both insiders and outsiders. Crucially, we show how the borrowing of codes and templates takes place across movements and markets to make de-essentialization and commodification possible. We suggest that the creation of thriving markets around counter-cultural movements cannot simply be defined as cooptation, whereby market actors extend their reach. Instead, this is a process replete with tensions, and driven by agency from both movement insiders and entrepreneurs, as well as enabled by the context in which local movements, markets, and social currents shape the trajectory that the focal movement takes.

\section{Limitations and Avenues for Future Research}

Not every movement successfully becomes a market. As Weber, Heinze, and DeSoucey (2008) argued, whereas a market emerged around grass-fed beef, the comparable movement of biodynamic farming did not spur a market. Similarly, the ancient Chinese practice of Tai Chi rooted in Taoist philosophy has not become a market, despite widespread recognition. Also, unlike yoga, praying for Muslims has not been de-essentialized. It is not just a form of physical exercise but derives its meaning entirely from the foundational religious teachings of the 
Quran, and Muslims around the world continue to treat the postural aspect of the practice as sacred and intimately tied to the original teachings. It would be instructive to study other movements (e.g., Vipassana, mindfulness, etc.) which followed a different route than yoga.

Also, although we studied desacralization, values and practices can equally become sacralized and de-commodified. Zelizer's (1985) study of the "sacralization of child life" — a shift from children being economically "useful" (contributors to family income) towards being economically "useless" (even costly to parents) but emotionally priceless-falls into this category. Given the overlap between sacralization and selective desacralization, it is worth examining secular enchantment, or the sacralization of the mundane. The sacred is not limited to the religious or spiritual, but also describes 'something 'set apart,' regardless of whether it is distinct because it is exalted or because it is fouled" (Rossman, 2014, p. 44). For instance, the meditative cycling brand SoulCycle is not just selling an exercise class, but a sacralized dream of purification, material improvement, and spiritual transcendence (Burton, 2020).

It would be equally useful to study instances of cultural reappropriation. For example, a resignified form of yoga is being re-exported to yoga's birthplace, India (Antony, 2018), provoking resistance among Hindu nationalists but also entrepreneurship to capitalize on its economic potential, as illustrated by a yoga guru's highly successful range of Patañjali consumer products in India. Although yoga was a movement rooted in Eastern philosophy and Hinduism, after its makeover in the West, the meaning of authentic is now up for grabs. Even people seeking "authentic" yoga in the East have reported visiting Westernized yoga centers offering instant gratification instead of original establishments offering traditional meditation, which attract a limited clientele in today's time-starved world. Although yoga was imported from India, it became Americanized as a result of borrowing codes from local movements (i.e., the NAM). It would be interesting to examine yoga's translation in other contexts, where local movements may cross pollinate it in different ways. 
In a world facing increasing pressures for marketization, it would be fruitful to further explore the movement-market nexus. Although much research has focused on how movements shape markets, more work needs to be done on how market imperatives put pressure on movements to change. Consider how the market for Black Lives Matter merchandise has increased exponentially since 2012; arguably, the discourse has been commodified through exploitation in pop culture, social media, and corporate advertising. Creating a brand out of a social problem and promoting pervasive commodification may arguably dilute the political and philosophical debates on the issue, as we have seen in other emancipatory movements such as the leftist Che Guevara movement. Yet, if commodification to varying degrees is unavoidable in modern society, can it serve to raise awareness and impact to help the cause it leverages?

The popularity of movements, even those that do not lend themselves well to markets, makes them an inviting target for corporate participation. It would be interesting to examine how counterculture went corporate in spiritual centers like the Esalen Institute in California, described as Hippie Inc., providing mysticism with a measurable return on investment (Segnit, 2019), and how communal living ideas were translated into the idea of a platform for shared workspaces (i.e., We Work). It would also be intriguing to study the sacralization and decommodification of markets, as well as cases of "failed marketization," where the nature of market relations cannot be reconciled that of social relations (Turco, 2012; Vermeulen, Ansari and Lounsbury, 2016). The tensions between counter-cultural movements and contemporary markets and how they are reconciled continues to be a fruitful research endeavor. 


\section{REFERENCES}

Agnew, T.

1976 "Yogeconomics: What kind of an economic system would be compatible with a yogic philosophy?” Yoga Journal, March.

Akemu, O., G. Whiteman, and S. Kennedy

2016 "Social enterprise emergence from social movement activism: The Fairphone case." Journal of Management Studies, 53: 846-877.

Alexander, $\mathrm{H}$.

2014 "India's yoga minster aims to reclaim practice from West." The Telegraph. December 3. https://www.telegraph.co.uk/news/worldnews/asia/india/11271782/Indias-yoga-minsteraims-to-reclaim-practice-from-West.html.

Almandoz, J., M. Lee, and C. Marquis

2017 "Different shades of green: Environment uncertainty and the strategies of hybrid organizations." Research in the Sociology of Organizations, 50: 31-67.

Almeling, R.

2007 "Selling genes, selling gender: Egg agencies, sperm banks, and the medical market in genetic material." American Sociological Review, 72(3), 319-34.

Amodeo, J.

1978 "The one way - a new spirit of ecumenicalism." Yoga Journal, November-December: $39-40$.

Andreasson, J., and T. Johansson

2018 "Glocalised fitness: The franchising of a physical movement, fitness professionalism and gender." Leisure/Loisir, 42: 301-321. doi:10.1080/14927713.2018.1535910.

Andretta, M., D. della Porta, and C. Saunders

2019 "Globalization and social movement." In D. Snow, S. A. Soule, H. Kriesi, and H. J. McCammon (eds.), The Wiley Blackwell Companion to Social Movements: 602-617.

Hoboken, NJ: Wiley Blackwell.

Anteby, M.

2010 "Markets, morals, and practices of trade: Jurisdictional disputes in the U.S. commerce in cadavers." Administrative Science Quarterly, 55: 606-638.

Appadurai, A.

2005 "Definitions: Commodity and Commodification." In M. Ertman and J. C. Williams (eds.), Rethinking Commodification: Cases and Readings in Law and Culture: 35. New York: New York University Press.

Armendariz B., and A. Szafarz

2011. "On mission drift in microfinance institutions." In B. Armendariz and M. Labie (eds.) The Handbook of Microfinance: 341-366. Singapore: World Scientific Publishing. 
Barrett, J.

2000 "Wag the down dog." Yoga Journal, May-June: 80-86.

Bartley, T.

2007 "Institutional emergence in an era of globalization: The rise of transnational private regulation of labor and environmental conditions." American Journal of Sociology, 113: 297351.

Bateman, M.

2011 Confronting Microfinance. Sterling, VA: Kumarian Press.

Bekerman, Z., M. Zembylas, and C. McGlynn

2009 "Working toward the de-essentialization of identity categories in conflict and post conflict societies: Israel, Cyprus, and Northern Ireland." Comparative Education Preview, 65: 213-234.

Bikram Yoga

2015 "Franchise." http://www.bikramyoga.com/franchise.

Binkley, S., and J. Littler

2011 Cultural studies and anti-consumerism. Oxford, UK: Routledge.

Bodian, S.

1985. Editorial. Yoga Journal, July/August: 4.

Bodian, S.

1991 Yoga Journal for Health and Conscious Living July/August 1991 Issue 99.

Boucher, G.

2006 "Fractured identity and agency and the plays of Adrienne Kennedy." Feminist Review, 84: 84-103.

Brabazon, $\mathrm{T}$.

2006 "Fitness is a feminist issue." Australian Feminist Studies, 21: 65-83.

Brezinski, M.

2005 "Hot yoga burns bright." CBS News. June 8.

Briscoe, F., and A. Gupta

2016 "Social activism in and around organizations." Academy of Management Annals, 10: $671-727$.

Brown, D., and A. Leledaki

2010 "Eastern movement forms as body-self transforming cultural practices in the West:

Towards a sociological perspective." Cultural Sociology, 4: 123-154.

doi:10.1177/1749975509356866

Burton, T. I.

2020. Strange Rites: New Religions for a Godless World. BBS. Public Affairs, NY. 
Calhoun, C.

2012 The Roots of Radicalism: Tradition, the Public Sphere, and Early Nineteenth-Century Social Movements. Chicago: Chicago University Press.

Carette, J., and R. King

2005 Selling Spirituality: The Silent Takeover of Religion. Oxford: Routledge.

Carroll, G., and A. Swaminathan

2000 "Why the microbrewery movement? Organizational dynamics of resource partition." American Journal of Sociology, 106: 715-762.

Catalfo, P.

1981 "Is yoga a religion?" Yoga Journal, May-June: 31-34.

Chasin, A.

2000 Selling Out. The Gay and Lesbian Movement Goes to Market. New York: St.

Martin's Press.

Cini, L., D. Chironi, E. Drapalova, and F. Tomasello

2017 "Towards a Critical Theory of Social Movements: An Introduction." Anthropological Theory, Vol. 17(4) 429-452.

Cohen, E.

2017 "Cutting the Buddha's body to fit the neoliberal Suit: Mindfulness: From practice, to purchase, to praxis.” Annual Review of Critical Psychology, 13 1-18.

Connare, C.

2000 "Yoga sells...Zippos?" Yoga Journal, November/December: 22-23.

Conrad, P.

1994 "Wellness as virtue: Morality and the pursuit of health culture." Medicine and Psychiatry, 18: 385-401.

Crossley, N.

2015 "Relational sociology and culture: A preliminary framework." International Review of Sociology, 25: 65-85.

Danforth, L.M.

1989 Firewalking and Religious Healing: The Anastenaria of Greece and the American Firewalking Movement. Princeton University Press, Princeton, NJ.

Davis, G. F., C. Morrill, H. Rao, and S. A. Soule

2008 "Introduction: Social movements in organizations and markets." Administrative Science Quarterly, 53: 389-394.

de Bakker, F. G. A., F. den Hond, B. King, and K. Weber

2013 "Social movements, civil society and corporations: Taking stock and looking ahead." Organization Studies, 34: 20.

De Michelis, E. 
2004 A History of Modern Yoga: Patañjali and Western Esotericism. London: Continuum.

Dioun, C.

2018 "Negotiating moral boundaries: Social movements and the strategic (re)definition of the medical in cannabis markets." Research in the Sociology of Organizations, 56, 53-82.

Durkheim, E.

1915 The Elementary Forms of Religious Life. London: George Allen and Unwin.

Edwards, B., and J. D. McCarthy

2004 Resources and social movement mobilization. In D. A. Snow, S. A. Soule, and H. Kriesi (eds.), The Blackwell Companion to Social Movements: 116-152. Hoboken, NJ:

Blackwell.

Eliade, $\mathrm{M}$.

1959 The Sacred and the Profane; the Nature of Religion. New York: Harcourt.

Eliade, $\mathrm{M}$.

2009 Yoga: Immortality and Freedom, Princeton, NJ, Princeton University Press.

Ellingson, S.

2013 "Packaging religious experience, selling modular religion: Explaining the emergence and expansion of megachurches." In F. Gauthier and T. Martikainen (eds.) Religion in Consumer Culture: 59-74. Surrey: Ashgate.

Eisenhardt, K.

1989 "Building theories from case study research. Academy of Management Review." 14: $532-550$.

Espeland, W., and M. Stevens

1998 "Commensuration as a social process." Annual Review of Sociology, 24: 313-343.

Fish, A.

2014 "Authorizing yoga: The pragmatics of cultural stewardship in the digital era." East Asian Science, Technology and Society, 84: 439-460.

Fligstein, N., and D. McAdam

2011 "Toward a general theory of social action fields." Sociological Theory, 29: 1-26.

Fominaya C.F., and L. Cox (Eds.)

2013 Understanding European Movements: New Social Movements, Global Justice Struggles, Anti-Austerity Protest. Mahwah, NJ: Routledge.

Fourcade, M.

2012 "The moral sociology of Viviana Zelizer.” Sociological Forum 27: 1055-1061.

Fourcade, M., and K. Healy

2007 "Moral views of market society." Annual Review of Sociology, 33: 14.1-14.27.

Frank, D., A. Hironaka, and E. Schofer 
2000 "The nation-state and the natural environment over the twentieth century." American Sociological Review, 65: 96-116.

Giddens, A.

1991 Modernity and Self-Identity; Self and Society in the Late Modern Age. Cambridge, UK: Polity Press.

Goldner, $\mathrm{M}$.

2001 "Expanding Political Opportunities and Changing Collective Identities in the Complementary and Alternative Medicine Movement." Pp. 69-102 in Political Opportunities, Social Movements, and Democratization, vol. 23, Research in Social Movements, Conflicts and Change, edited by Patrick G. Coy. Greenwich, CT: JAI Press/Elsevier Science.

Goyeche, J.

1976 "How to die according to the Bhagavad Gita." Yoga Journal, July.

Green, $\mathrm{H}$.

1986 Fit For America: Health, Fitness, Sport and American Society: New York, US: Pantheon.

Gümüsay, A., M. Smets, and T. Morris

2019 "'God at work': Engaging central and incompatible institutional logics through elastic hybridity." Academy of Management Journal, 63: 124-154.

Gurin, J., and T. G. Harris

1987 "Taking charge." American Health, March: 53-57.

Healy. K.

2004 "Altruism as an organizational problem: the case of organ procurement." American Sociological Review, 69, 387-404.

Hedberg, L., and M. Lounsbury

Forthcoming. Not Just Small Potatoes: Cultural Entrepreneurship In The Moralizing Of Markets, Organization Science.

Heelas, P.

1996 The New Age Movement: The Celebration of the Self and the Sacralization of Modernity. Oxford, UK: Blackwell.

Herriott, E., J. Schmidt-Wilk, and D. P. Heaton

2009 "Spiritual dimensions of entrepreneurship in transcendental meditation and TM-Sidhi program practitioners.” Journal of Management, Spirituality \& Religion, 6: 195-208.

Hiatt, S., W. Sine, and P. Tolbert

2009 "From Pabst to Pepsi: The deinstitutionalization of social practices and the emergence of entrepreneurial opportunities." Administrative Science Quarterly, 54: 635-667.

Hines, A.

2019 "Inside CorePower yoga teacher training." The New York Times, April 6. 
Hirschman A. O.

1982 Rival interpretations of market society: Civilizing, destructive, or feeble? Journal of Economic Literature. 20: 1463-1484.

Hirschman, E., and P. LaBarbera

1989 "The meaning of Christmas." In E. C. Hirschman (ed.), SV Interpretive Consumer Research: 136-147. Provo, UT: The Association for Consumer Research.

Hitlin, S., and S. Vaisey

2013 "The new sociology of morality." Annual Review of Sociology, 39: 51-68.

Hugo, V.

1896. Toilers of the Sea. Routledge. UK.

Jain, A.

2014 Selling Yoga: From Counterculture to Pop Culture, UK. Oxford University Press.

Khaire, M. and Wadhwani. D.R.

2010 "Changing Landscapes: The Construction of Meaning and Value in a New Market Category-Modern Indian Art." Academy of Management Journal, Vol. 53, No. 6: 12811304.

Khalsa, P.

1979 "The business of consciousness." Yoga Journal, May.

Khalsa, S. B. S., L. Hickey-Schultz, D. Cohen, N. Steiner, and S. Cope

2012 "Evaluation of the mental health benefits of yoga in a secondary school: a preliminary randomized controlled trial." Journal of Behavioral Health Services \& Research. Jan, 39(1):80-90.

King. L. and Gish, E.

2015 "Marketizing Social Change: Social Shareholder Activism and Responsible Investing." Sociological Perspectives. Vol. 58(4): 711-730.

King, B., and N. Pearce

2010 "The contentiousness of markets: Politics, social movements, and institutional change in markets." Annual Review of Sociology, 36: 249-267.

Kubicek, I.

2014 "Our exclusive interview with Tara Stiles in London." Om Exchange.

http://omexchange.com/our-exclusive-interview-with-tara-stiles-london/.

Lane, M.

2003 "The tyranny of yoga." BBC News Online, October 9.

http://news.bbc.co.uk/1/hi/magazine/3174356.stm.

Laraña, E., H. Johnston, and J. Gusfield

1994 New Social Movements: From Ideology to Identity. Philadelphia, PA: Temple

University Press. 
Lasater, J.

2010 "Letter to the Editor." Yoga Journal, September: 25-26.

Lee, B., S. Hiatt, and M. Lounsbury

2017 "Market mediators and the trade-offs of legitimacy-seeking behaviours in a nascent category." Organization Science, 28: 447-470.

Lee, M., T. Ramus, and A. Vaccaro

2018 "From protest to product: Strategic frame brokerage in a commercial social movement organization." Academy of Management Journal, 61: 2130-2158.

Leopold, A.

2001 "The architecture of syncretism: A methodological illustration of the dynamics of syncretism." Historical Reflections, 27: 401-423.

Lounsbury, M., M. Ventresca, and P. Hirsch

2003 "Social movements, field frames and industry emergence: A cultural-political perspective on U.S. recycling." Socio-Economic Review, 1: 71-104.

Marx, K.

1867 Capital Volume 1. New York: International Publishers. Marxists.org.

Maurer, D.

2002 Vegetarianism: Movement or Moment. Promoting a Lifestyle for Cult Change. Philadelphia, PA: Temple University Press.

Mars, M., and M. Lounsbury

2009 "Raging against or with the private marketplace? Logic hybridity and ecoentrepreneurship." Journal of Management Inquiry, 18: 4-13.

McInerney, P.-B.

2014 From social movement to moral market: How the Circuit Riders sparked an IT revolution and created a technology market. Stanford, CA: Stanford University Press.

Medin, R. A.

2014 "3 Gurus, 48 Questions. Matching interviews with Sri T. K. V. Desikachar, Sri, B. K.

S. Iyengar, and Sri K. Pattabhi Jois." Namarupa, 12: 6-18.

Melillo, W.

2003 "Ohm no!" AdWeek: Art \& Commerce, January 6.

http://www.adweek.com/news/advertising/art-commerce-ohm-no-60730

Meyer, D., and N. Whittier

1994 "Social movement spillover." Social Problems, 41: 277-298.

Michelon, M., Rodrigue, M., and E. Trevisan

2020 "The marketization of a social movement: Activists, shareholders and

CSR disclosure." Accounting, Organizations and Society, 80, 101074. 
Montemaggi, F.

2013 "Shopping for a church? Choice and commitment in religious behaviour." In: F. Gauthier and T. Martikainen (eds.), Religion in Consumer Culture: 109-124. Surrey, UK: Ashgate.

Morth, I.

1989 "New Age — neue Religion? Theoretische U” berlegungen und empirische Hinweise zur sozialen Bedeutung des Wendezeit-Syndroms." In Haller, M.; Hoffmann-Novottny, H. G. \& Zapf, W., eds. Kultur und Gesellschaft. Frankfurt, New York: Campus, 297-320.

Munir, K.A. and Phillips, N.

2005 "The birth of the Kodak moment: institutional entrepreneurship and the adoption of new technologies." Organization Studies, 26(11): 1665-1687.

Muraca, B.

2013 "Décroissance: A project for a radical transformation of society." Environmental Values, 22: 147-169.

Paliwall, P.

1976 "Gandhi and the Gita." Yoga Journal, May.

Paull, S.

1977 "The meeting of East and West." Yoga Journal, July/August: 4-5.

Pavia, W.

2013 Financial advisers seek inner peace — and big profits. The Times. June 11. http://www.thetimes.co.uk/tto/news/world/americas/article3787675.ece.

Peifer, J.L., DR. R. Johnson and E. H. Eckland 2020 Is the Market Perceived to be Civilizing or Destructive? Scientists' Universalism Values and Their Attitudes Towards Patents. Journal of Business Ethics. Journal of Business Ethics https://doi.org/10.1007/s10551-020-04633-y

Philip, J., and D. Mercer

1999 "Commodification of Buddhism in contemporary Burma." Annals of Tourism Research, 26: 21-54.

Pickering, W.

1975 Durkheim on Religion: A Selection of Readings and Bibliographies. Boston, MA: Routledge and Kegan Paul.

Pontikes, E.

2012 "Two sides of the same coin: How ambiguous classification affects multiple audiences' evaluations." Administrative Science Quarterly, 57: 81-118.

Pratt, M., K. W. Rockmann, and J. B. Kaufmann

2006 "Constructing professional identity: The role of work and identity learning cycles in the customization of identity among medical residents." Academy of Management Journal, 49: 235-262. 
Purser, R. E., and J. Milillo

2015. "Mindfulness revisited: A Buddhist-based conceptualization." Journal of Management Inquiry, 24: 3-24.

Purser, R. E. (2019) McMindfulness: How Mindfulness Became the New Capitalist Spirituality. New York: Watkins Media Ltd.

Putney, C.

2001 Muscular Christianity. Manhood and Sports in Protestant America, 1880-1920.

Cambridge, MA: Harvard University Press.

Quinn, S.

2008 "The inversion of morals in markets: Death, benefits and the exchange in life insurance policies." American Journal of Sociology, 114: 738-780.

Radin, M.

1996 Contested Commodities. Cambridge, UK: Cambridge University Press.

Rankin, A.

1978. "Standards for yoga teachers" Yoga Journal. July: 45-47.

Rankin, A.

1980. "Oracles of the New Age" Yoga Journal. January: 7-10.

Rao, H., P. Monin, and R. Durand

2005 "Border Crossing: Bricolage and the Erosion of Categorical Boundaries in French Gastronomy, American Sociological Review, Vol. 70, No. 6, pp. 968-991.

Reich, A.

2014 "Contradictions in the commodification of hospital care." American Journal of Sociology, 119: 1576-1628.

Reinecke, J., and S. Ansari

2015 "What is a 'fair' price? Ethics as sensemaking." Organization Science, 26: 867-888.

Reinecke, J. and S. Ansari, S.

2020 Microfoundations of Framing: The Interactional Production of Collective Action

Frames in the Occupy Movement, Forthcoming in Academy of Management Journal.

Ritzer, G.

2000 The McDonaldization of Society. Thousand Oaks, CA: Pine Forge.

Robitaille, L.

2014 "Promoting capoeira, branding Brazil: A focus on the semantic body." Black Music Research Journal, 34: 229-254.

Roszak, T.

1995 The Makings of a Counter-Culture. Reflections on the Technocratic Society and Its Youthful Opposition. Berkeley, CA: University of California Press. 
Rojas, F and B. King

2018 "How Social Movements Interact with Organizations and Fields Protest, Institutions, and Beyond." In D. A. Snow, S.A. Soule, H. Kriese, H.J. McCammon (eds.) The Wiley Blackwell Companion to Social Movements, $2^{\text {nd }}$ Edition:

Chapter 11, 203-219. New Jersey: Wiley Blackwell.

Rossman, G.

2014 "Obfuscatory relational work and disreputable exchange." Sociological Theory, 32(1), $43-63$.

Roy, S.

2008 "'Taking charge of your health': Discourses of responsibility in English-Canadian women's magazines." Sociology of Health and Illness, 30: 463-477.

Salmon, J. W., and H. S. Berliner

1979 "The holistic health movement and scientific medicine: The naked and the dead." Socialist Review, 43: 31-52.

Salmon, J. W., and H. S. Berliner

1980 "The holistic health movement: Challenges to health planning." Health Law Project Library Bulletin, March: 60-67.

Sandel, M. J.

2012 What Money Can't Buy: The Moral Limits of Markets. London: Penguin UK.

Santos, J. and Avery, C.

2016 The Talon. October 18, https://lahstalon.org/the-commodificationof-a-culture-punkfashion-goes-mainstream/The Commodification of a Culture:

Punk Fashion Goes Mainstream.

Saraswati, S.

1976 Commentary on the Yoga Sutras of Patañjali. Bihar: Bihar School of Yoga.

Sattin, J. and Woodhall, V.

2013 Everyone Triyoga: Finding Your Yoga Fit. London: Kyle Books.

Schiller-Merkens, S. and P. Balsiger

2019 Moral struggles in and around markets. Research on the Sociology of Organizations. Bingley, West Yorkshire, England: Emerald Insights.

Schultz, M. M.

1997 "Questioning commodification. Reviewed work(s): Contested commodities: The trouble with trade in sex, children, body parts, and other things by Margaret Jane Radin." California Law Review, 85: 1841-1860.

Segnit, N.

2019 "Stories of an extraordinary world. Hippie Inc: How the counterculture went corporate." The Economist. November 29.

Shoval, N. 
2000 "Commodification and theming of the sacred: Changing patterns of tourist consumption in the Holy Land." In M. Gottdiener (ed.), New Forms of Consumption: Consumers, Culture, and Commodification: 251-262. Boulder, CO: Lanham.

Simmel, G.

1978 The Philosophy of Money. Translated by Tom Bottomore and David Frisby. London: Routledge and Kegan Paul.

Sine, W., H. Haveman, and P. Tolbert

2005 "Risky business? Entrepreneurship in the new independent power sector."

Administrative Science Quarterly, 50: 200-232.

Sinha, K.

2011 Sinha Kounteya. India Pulls the Plug on Yoga as Business, The Times of India, February 6. Available at http://articles.timesofindia.indiatimes.com/2011-02-

06/india/2835560 2_1_hot-yoga-patanjali-tkdl

Snow, D. A., S. Soule, and H. Kriesi

2004 The Blackwell Companion to Social Movements. Oxford, UK: Blackwell.

Soule, S., and B. King

2015 "Markets, business, and social movements." In D. Della Porta and M. Diani (eds.), The Oxford Handbook of Social Movements: 696-710. Oxford, UK: Oxford University Press.

Stehr, N.

2008 The moralization of the markets in Europe. Global Society, 45(1), 62-67.

Stern, M.

2009 "The fitness movement and the fitness center industry, 1960-2000." Business and Economic History, 6.

Stewart, C. and C. Shaw

1994. Syncretism/Anti-syncretism: The politics of religious synthesis. London, Routledge.

Stiles, T.

2010. Slim, Calm, Sexy Yoga: The 15-Minute Yoga Solution for Feeling and Looking Your Best from Head to Toe. NY, USA. Rodale, Inc.

Strauss, S.

2004 "Re-orienting yoga." Expedition, 46, 29-34.

http://www.penn.museum/sites/expedition/?p=8855

Suber, $\mathrm{P}$.

2007 Creating an intellectual commons through open access. In C. Hess \& E. Ostrom

(Eds.), Understanding knowledge as a commons: from theory to practice (pp. 171-208).

Cambridge, MA: MIT Press.

Swidler, A.

1986 "Culture and action: Symbols and strategies." American Sociological Review, 51: 
Thananusak, T. and S. Ansari.

2019 Knowledge Production and Consumption in the Digital Era: The Emergence of Altmetrics and Open Access Publishing in Management studies" In The Production of Managerial Knowledge and Published online: 27 Mar 2019; 77-102.

Turco, C.

2012 Difficult decoupling: Employee resistance to the commercialization of personal settings. American Journal of Sociology, 118, 380-419.

Turner, B. S.

1991 Religion and Social Theory. London: Sage.

\section{U.S. Patent Office}

2016 "Trademark electronic search system." http://www.tmsearch.uspto.gov

Antony, M. G.

2018 That's a Stretch: Reconstructing, Rearticulating, and Commodifying Yoga, Front. Commun., 33 (47). doi: 10.3389/fcomm.2018.00047.

Van Stekelenburg, J., C. Roggeband, and B. Klandermans

2013 "Introduction. The future of social movement research." Social Movements, 39: xixxii. Minneapolis, MN: University of Minnesota Press.

Vasi, I.B.

2011 Winds of change: The environmental movement and the global development of the wind energy industry, Oxford University Press.

Vermeulen, P. Ansari, S., and Lounsbury, M.

2016 Understanding "Failed" Markets: Conflicting Logics and Dissonance in Attempts to Price the Priceless Child. Article in Research in the Sociology of Organizations. 48B: 37-68.

Vivekananda, S.

1947 The Complete Works of Swami Vivekananda, Volume 3. A. Ashram (ed.) Kolkata: Advaita Ashram.

Walder, A.

2009 "Political sociology and social movements." Annual Review of Sociology, 35: 393412.

Walzer, M.

1983 Spheres of Justice: A Defense of Pluralism and Equality. New York: Basic Books.

Wang, D., A. Piazza, and S. Soule

2018 "Boundary spanning in social movements." Annual Review of Sociology, 44: 167187.

Weber, K., K. Heinze, and M. DeSoucey

2008 "Forage for thought: Mobilizing codes in the movement for grass-fed meat and dairy 
products." Administrative Science Quarterly, 53: 529-567.

Weber, M.

1930 The Protestant Work Ethic and the Spirit of Capitalism. T. Parsons (trans.). London: Unwin Hyman.

White, J.

1977 “Gurus and politics.” Yoga Journal, May/June.

Whittier, N. E.

2002 Meaning and structure in social movements. In D. S. Meyer, N. Whittier, \& B.

Robnett (Eds.), Social movements: identity, culture, and the state. Oxford University Press.

Yi, J., and D. Silver

2015 "God, yoga and karate." Journal for the Scientific Study of Religion, 54: 596-615.

Yoga Journal and Yoga Alliance

2016 Yoga in America Study. San Francisco, CA: Ipsos Public Affairs.

York, J., S. Vedula, and M. Lenox

2017 "It's not easy building green: The impact of public policy, private actors, and regional logics on voluntary standards adoption." Academy of Management Journal, 61: 1492-1523.

York, M.

2001 "New Age commodification and appropriation of religion." Journal of Contemporary Religion, 16: 361-372.

Yue, L., J. Wang, and B. Yang

2018 "Contesting commercialization: Political influence, responsive authoritarianism, and cultural resistance." Administrative Science Quarterly, 64: 435-465.

Yunus, $\mathrm{M}$.

2011 "Sacrificing microcredit for megaprofits." The New York Times, January 14.

Zelizer, V.

1979 Morals and Markets: The Development of Life Insurance in the United States. New York: Columbia University Press.

Zelizer, V.

1985 Pricing the Priceless Child: The Changing Value of Children. Princeton, NJ:

Princeton University Press.

Zelizer, V.

2005 The Purchase of Intimacy. Princeton, NJ. Princeton University Press.

Zelizer, V.

2012 "How I Became a Relational Economic Sociologist and What Does That

Mean?" Politics and Society, 40 (2): 145-74. 


\section{FIGURES AND TABLES}

Figure 1. The rise and fall of various themes in Yoga Journal (1975-2016)

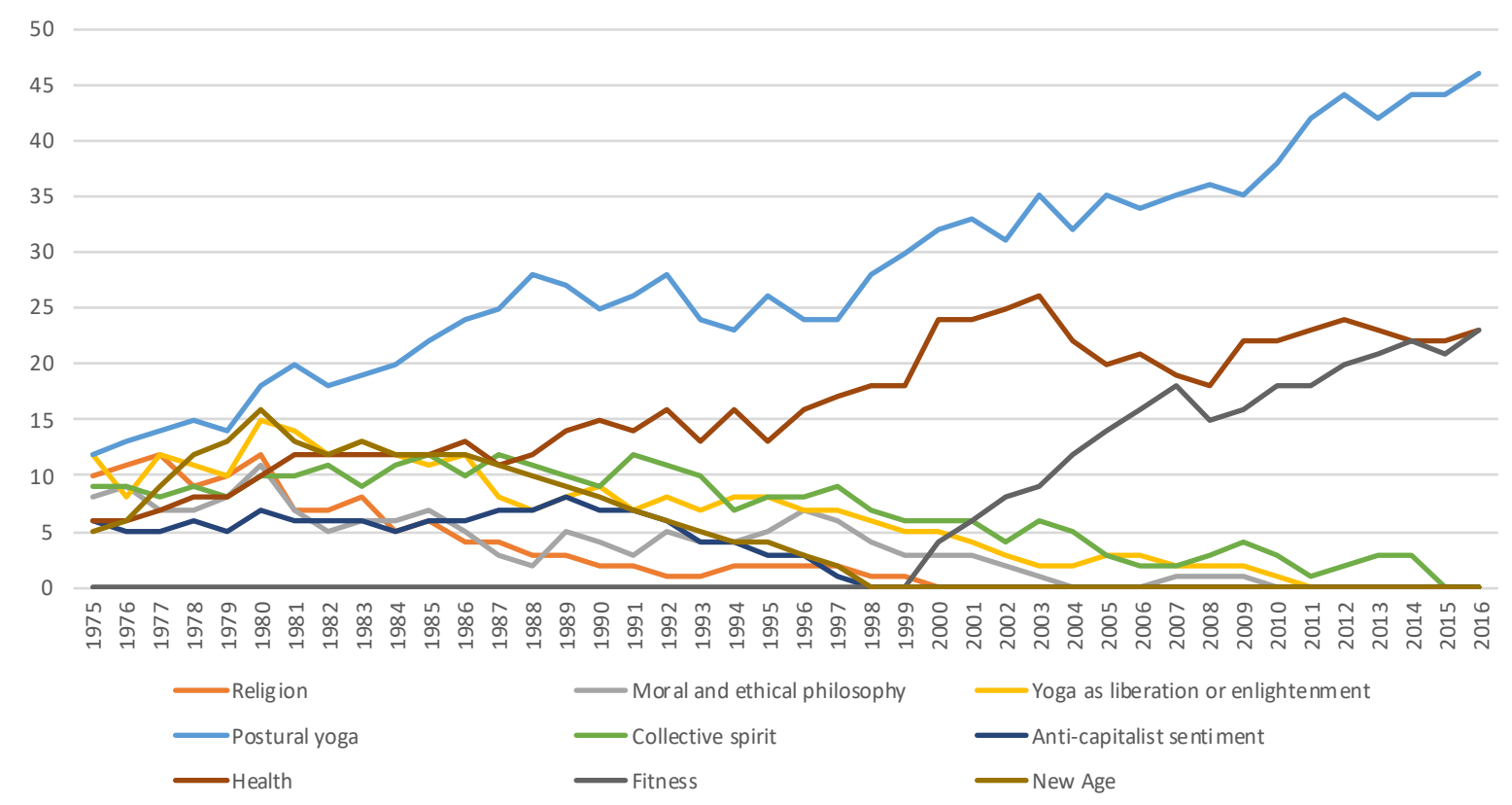


Figure 2. The evolution of Yoga Journal covers

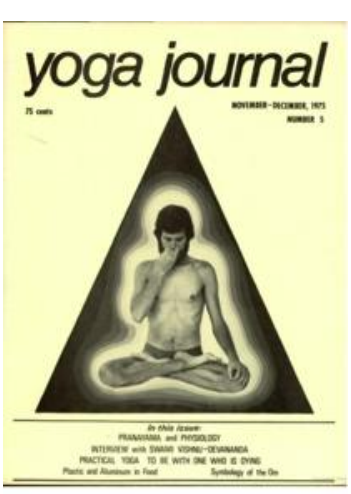

November-December 1975

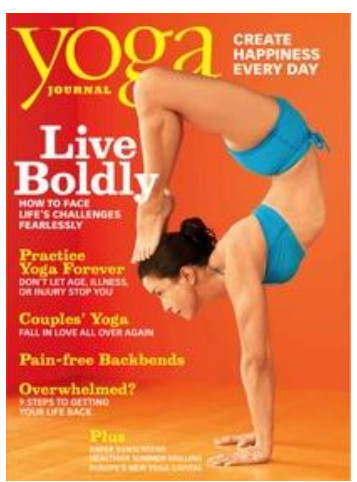

August 2005

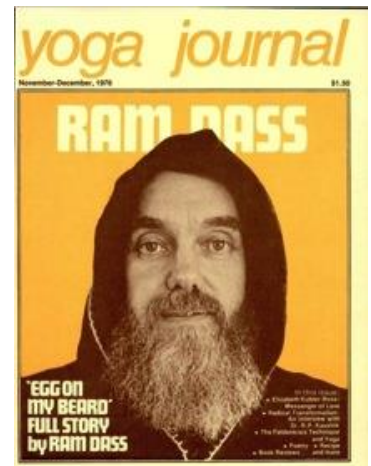

November-December 1976

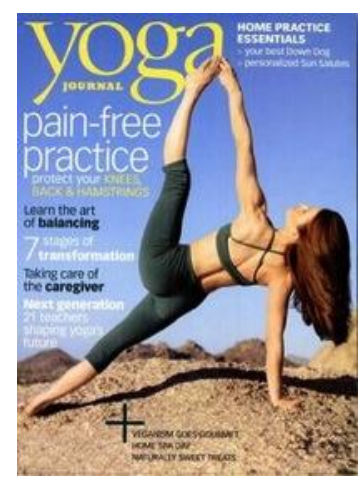

March 2008

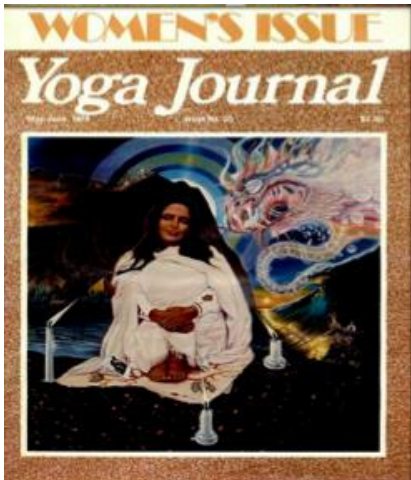

May-June 1978

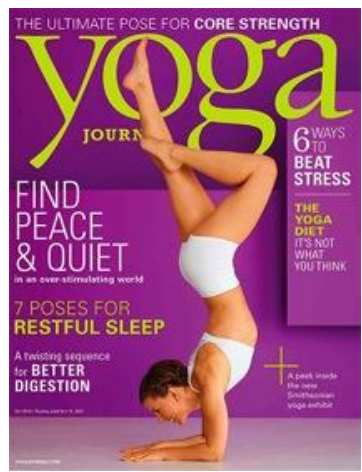

October 2013 
Figure 3. Terms associated with yoga in major U.S. newspapers, as a proportion of total articles mentioning yoga

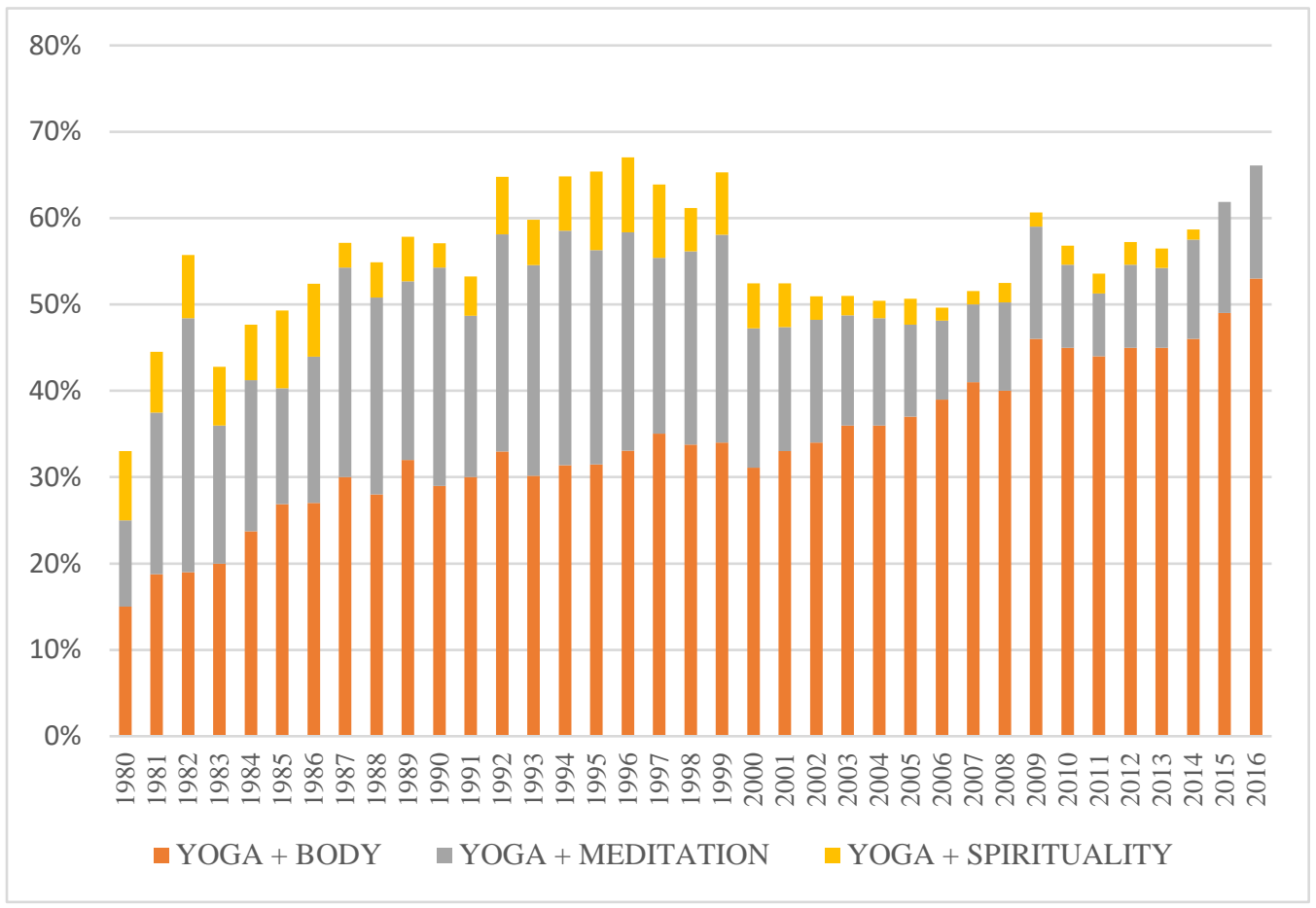

Figure 4. Forging new aspirations

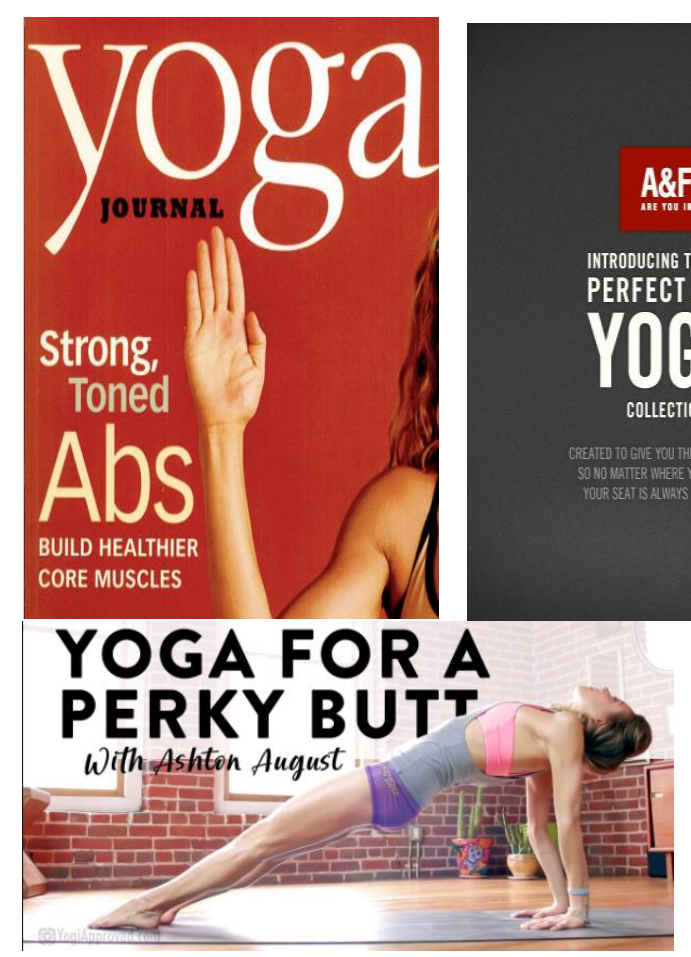


Figure 5. The media and yoga

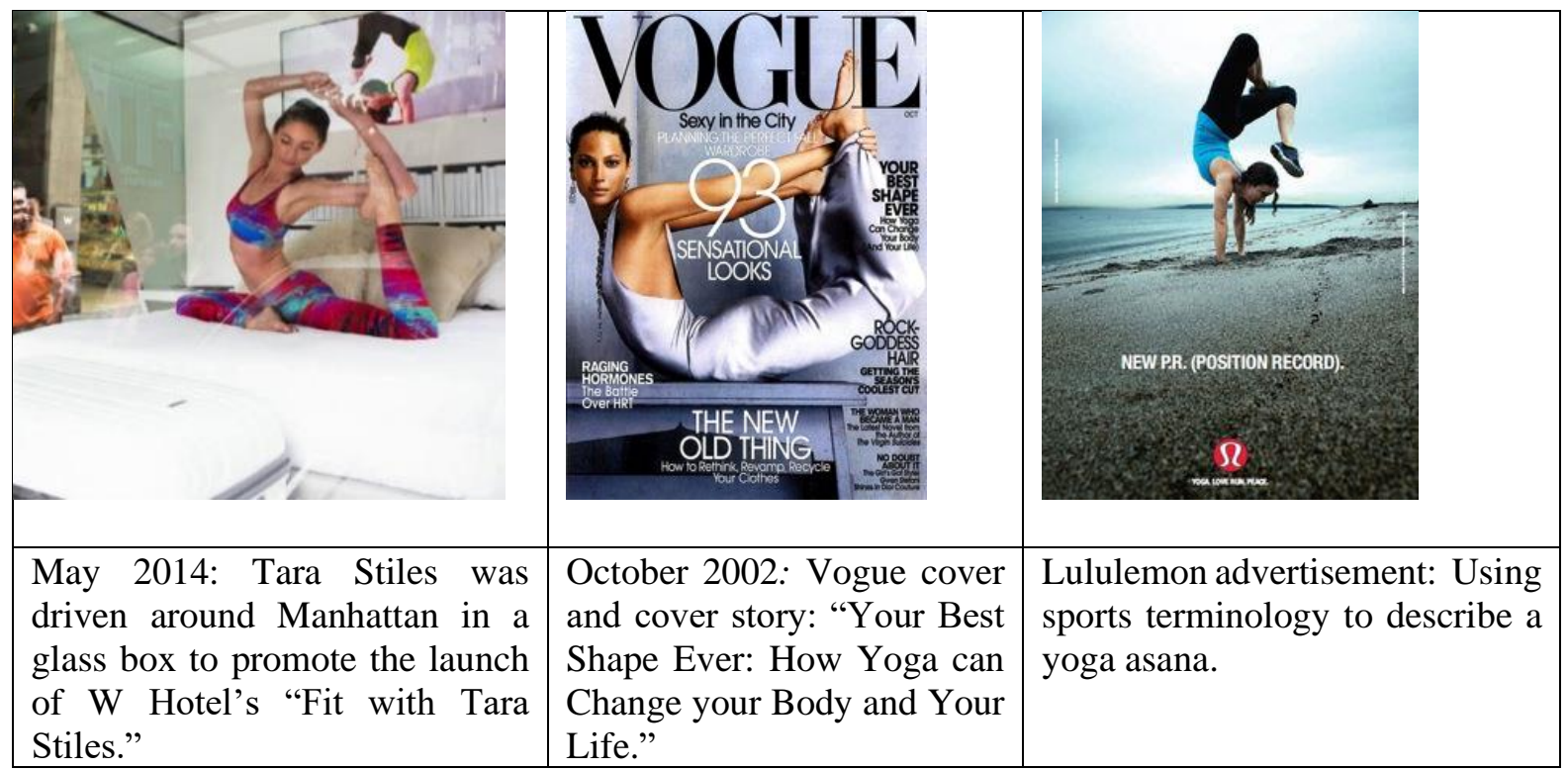


Figure 6. A model for the syncretization of movements with markets

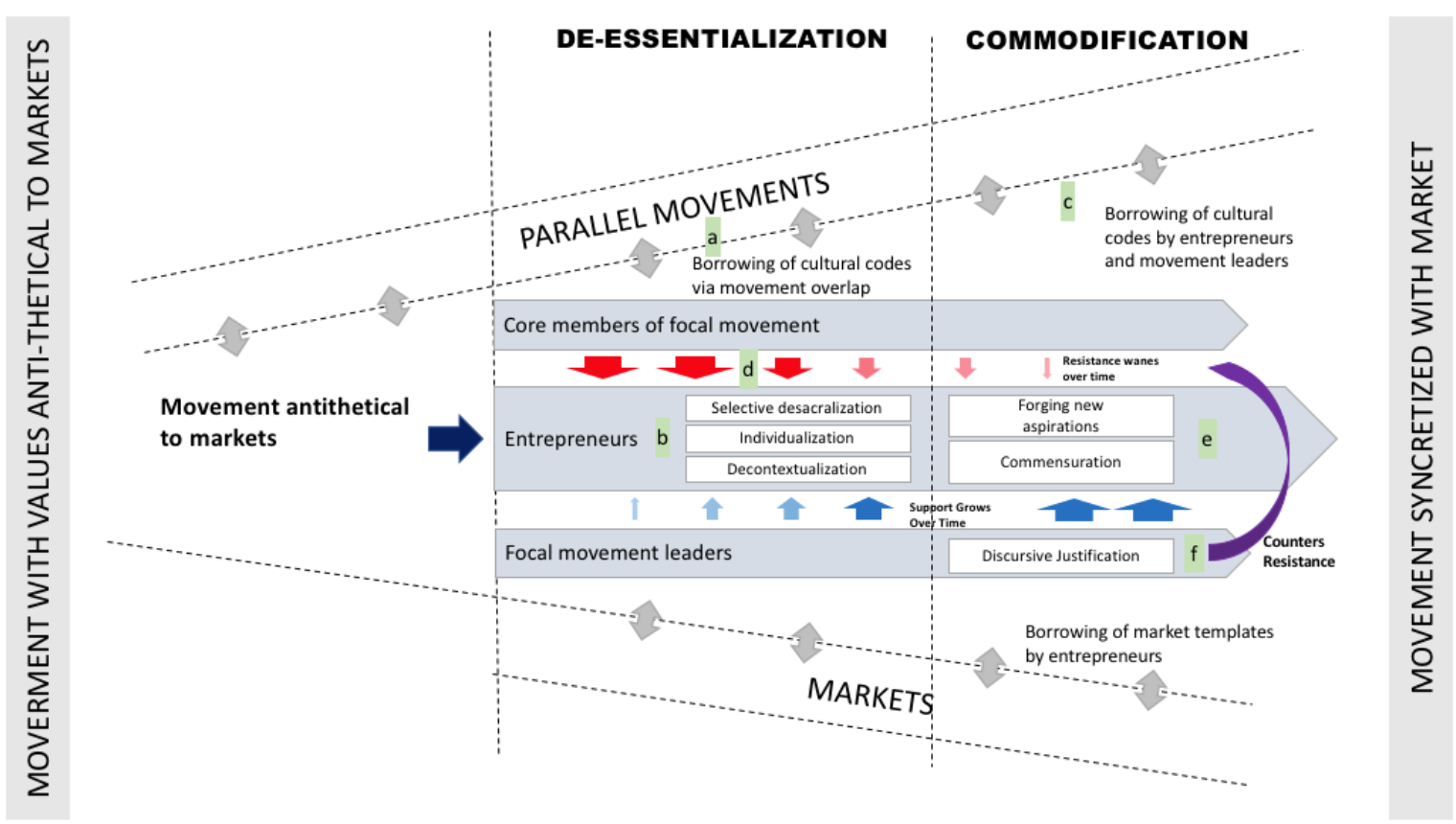


Table 1. Data sources

\begin{tabular}{|c|c|c|}
\hline Type & Description & Analysis \\
\hline \multirow[t]{4}{*}{ Secondary } & $\begin{array}{l}\text { Yoga Journal, the premier } \\
\text { and longest running journal } \\
\text { of the yoga movement (1975- } \\
\text { 2016) }\end{array}$ & $\begin{array}{l}\text { Performed comprehensive coding and } \\
\text { content analysis of } 240 \text { issues over } 40 \\
\text { years, looking for first order categories, } \\
\text { dominant themes over time, debates, } \\
\text { shifts in stance, engagement with other } \\
\text { movements, and responses to the } \\
\text { commodification of yoga. }\end{array}$ \\
\hline & $\begin{array}{l}\text { Other trade journals, } \\
\text { including Yoga for Health } \\
\text { and OM Yoga Magazine } \\
(1975-2016)\end{array}$ & $\begin{array}{l}\text { In-depth review of covers, all content and } \\
\text { advertising. }\end{array}$ \\
\hline & Major U.S. newspapers & $\begin{array}{l}\text { Searched Factiva for articles on yoga, } \\
\text { and the proportion of these articles that } \\
\text { discussed yoga with reference to the } \\
\text { body as opposed to meditation or } \\
\text { spirituality. }\end{array}$ \\
\hline & $\begin{array}{l}\text { Mainstream and academic } \\
\text { books written on yoga (1924- } \\
2016)\end{array}$ & $\begin{array}{l}\text { Bibliographic review of mainstream and } \\
\text { academic books on yoga. }\end{array}$ \\
\hline \multirow[t]{3}{*}{ Primary } & $\begin{array}{l}\text { Primary interviews: } 31 \text { formal } \\
\text { and } 36 \text { informal interviews } \\
\text { with teachers, studio owners, } \\
\text { entrepreneurs, and } \\
\text { practitioners (2013-2016) }\end{array}$ & $\begin{array}{l}\text { Transcribed interviews and input } \\
\text { transcripts into NVivo; coded and cross- } \\
\text { analyzed with discourse analysis to } \\
\text { ensure "lived experience" in line with } \\
\text { media coverage of yoga. }\end{array}$ \\
\hline & $\begin{array}{l}\text { Participant observation: } \\
\text { Participation in } 408 \text { yoga } \\
\text { classes in the United States, } \\
\text { the UK, and India; 200-hour } \\
\text { Yoga Alliance certified } \\
\text { teacher training (July 2013, } \\
\text { UK) }\end{array}$ & $\begin{array}{l}\text { Input field notes into NVivo to add } \\
\text { contextual understanding to the lived } \\
\text { practice of yoga. }\end{array}$ \\
\hline & $\begin{array}{l}\text { Conferences: British Wheel } \\
\text { of Yoga Congress (March } \\
\text { 2013); } \\
\text { Smithsonian Symposium on } \\
\text { "Yoga and the Art of } \\
\text { Transformation" (November } \\
\text { 2013) }\end{array}$ & Input field notes into NVivo. \\
\hline
\end{tabular}


Table 2. Interviews

\begin{tabular}{lcc}
\hline \multicolumn{1}{c}{ Type } & Formal & Informal \\
\hline $\begin{array}{l}\text { Entrepreneurs } \\
\text { Yoga clothing brands }\end{array}$ & 4 & 3 \\
$\quad$ Studio owners/managers & 5 & 1 \\
Teachers & 4 & 4 \\
Senior yoga teachers (from the 1970s) & 5 & 8 \\
Second-wave yoga teachers (1980s and 1990s) & 5 & 9 \\
New yoga teachers (2000s onward) & & \\
Practitioners & 3 & 1 \\
Long-term students (over 10 years of experience) & 2 & 4 \\
Medium-term students (over 5 years of experience) & 2 & 6 \\
$\quad$ New practitioners (less than 1 year of experience) & 1 & 0 \\
Other: Spiritual leader & 31 & 36 \\
\hline Total
\end{tabular}


Table 3. Coding scheme and theoretical dimensions

\begin{tabular}{|c|c|c|c|}
\hline First Order Categories & $\begin{array}{l}\text { Second Order } \\
\text { Themes }\end{array}$ & $\begin{array}{l}\text { Aggregate theoretical } \\
\text { Dimensions }\end{array}$ & Outcome \\
\hline $\begin{array}{l}\text { From religious to secular } \\
\text { and 'spiritual' }\end{array}$ & $\begin{array}{l}\text { Selective } \\
\text { Desaclarization }\end{array}$ & \multirow{6}{*}{ De-essentialization } & \multirow{12}{*}{ Syncretization } \\
\hline $\begin{array}{l}\text { Retention of some } \\
\text { religious symbolism }\end{array}$ & & & \\
\hline Depoliticization & Individualization & & \\
\hline Personalization & & & \\
\hline $\begin{array}{l}\text { Americanization and } \\
\text { breakage of lineage }\end{array}$ & Decontextualization & & \\
\hline $\begin{array}{l}\text { Mocking yoga's } \\
\text { complexity }\end{array}$ & & & \\
\hline $\begin{array}{l}\text { From enlightenment to } \\
\text { health and fitness }\end{array}$ & $\begin{array}{l}\text { Forging new } \\
\text { aspirations }\end{array}$ & \multirow{6}{*}{ Commoditization } & \\
\hline Makeover of yoga & & & \\
\hline $\begin{array}{l}\text { Standardization and } \\
\text { certification }\end{array}$ & Commensuration & & \\
\hline $\begin{array}{l}\text { From public to } \\
\text { proprietary }\end{array}$ & & & \\
\hline $\begin{array}{l}\text { Increasing need for } \\
\text { resources }\end{array}$ & \multirow[t]{2}{*}{$\begin{array}{l}\text { Discursive } \\
\text { Justification }\end{array}$} & & \\
\hline $\begin{array}{l}\text { Discursively balancing } \\
\text { movement and market } \\
\text { goals }\end{array}$ & & & \\
\hline
\end{tabular}


Table 4. Issues of importance to the yoga movement: Illustrative feature articles in Yoga Journal (1975-1980)

\begin{tabular}{ll}
\hline \multicolumn{1}{c}{ Theme } & \multicolumn{1}{c}{ Illustrative headlines } \\
\hline Religion & "Gandhi and the Gita" by Dr. Premlata Paliwal (May 1976) \\
& "How to die according to the Bhagavad Gita" by John Goyeche (July \\
\hline $\begin{array}{l}\text { Moral and } \\
\text { ethical } \\
\text { philosophy }\end{array}$ & $\begin{array}{l}\text { "Yogeconomics: What kind of an economic system would be compatible } \\
\text { "The business of consciousness" by Pramatma Khalsa (May 1979) }\end{array}$ \\
\hline $\begin{array}{l}\text { Yoga as } \\
\text { enlightenment } \\
\text { rather than } \\
\text { health }\end{array}$ & $\begin{array}{l}\text { "Yoga is a path to the truth, nothing more" Editorial (May 1976) } \\
\text { feet" Judith Lasater, Founding Editor (Interview) }\end{array}$ \\
\hline $\begin{array}{l}\text { Collective } \\
\text { spirit }\end{array}$ & "Gurus and politics" by John White (May/June 1977) \\
\hline $\begin{array}{l}\text { Anti-capitalist } \\
\text { sentiment }\end{array}$ & $\begin{array}{l}\text { "Vairagya: The renunciation of desires" by Swami Saraswati (September } \\
\text { "The business of consciousness" by Pramatma Khalsa (May 1979) }\end{array}$ \\
\hline
\end{tabular}


Table 5. Key cultural codes and templates borrowed from the New Age, holistic health, and fitness movements

\begin{tabular}{|c|c|c|}
\hline Movement & Influence on yoga & Quotations \\
\hline \multirow{3}{*}{$\begin{array}{l}\text { New Age } \\
\text { movement }\end{array}$} & Spirituality replaced religion & $\begin{array}{l}\text { "It would be better to use the word spirituality rather } \\
\text { than religion, simply because yoga does not have } \\
\text { any credos or congregations." (Yoga Journal regular } \\
\text { columnist Phil Catalfo, 1981) }\end{array}$ \\
\hline & $\begin{array}{l}\text { Yoga associated with the "age of } \\
\text { Aquarius" }\end{array}$ & $\begin{array}{l}\text { "It is in the spirit of wholeness-individual and } \\
\text { collective-that we will manifest the planetary } \\
\text { psyche of the Aquarian Age." (Yoga Journal } \\
\text { Editorial, November 1981) }\end{array}$ \\
\hline & $\begin{array}{l}\text { Practitioners encouraged to } \\
\text { define yoga for themselves }\end{array}$ & $\begin{array}{l}\text { "There are no rules in life and you need to follow } \\
\text { your intuition and what makes you feel good." (Tara } \\
\text { Stiles, one of the most well-known yoga instructors } \\
\text { in the world) }\end{array}$ \\
\hline \multirow{3}{*}{$\begin{array}{l}\text { Holistic } \\
\text { health } \\
\text { movement }\end{array}$} & $\begin{array}{l}\text { Yoga framed as a contributor to } \\
\text { "holistic health" }\end{array}$ & $\begin{array}{l}\text { "Certainly, the holistic health movement is making } \\
\text { inroads into the American consciousness. ... There } \\
\text { is a change in attitude that can even be perceived on } \\
\text { the six o'clock news. There is a new interest in } \\
\text { exercise, in proper nutrition, in natural childbirth and } \\
\text { breastfeeding, and one occasionally sees items about } \\
\text { bio-feedback, yoga, and acupuncture. Hooray for our } \\
\text { side." (Yoga Journal Editorial, September 1980) }\end{array}$ \\
\hline & $\begin{array}{l}\text { Yoga used as a remedy for } \\
\text { physical ailments }\end{array}$ & $\begin{array}{l}\text { "In 1976, I was asked to teach a yoga class to people } \\
\text { with back pain. It was a radical concept! We just } \\
\text { didn't think of yoga as a remedy for physical } \\
\text { ailments." (Interview with Judith Lasater, Founding } \\
\text { Editor of Yoga Journal). }\end{array}$ \\
\hline & $\begin{array}{l}\text { Yoga sold as a stress relief } \\
\text { technique }\end{array}$ & $\begin{array}{l}\text { "Less sick days, less stressed out employees. That } \\
\text { was what I was selling." (Interview with yoga } \\
\text { entrepreneur who sold workshops to corporations). }\end{array}$ \\
\hline \multirow{3}{*}{$\begin{array}{l}\text { Fitness } \\
\text { movement }\end{array}$} & $\begin{array}{l}\text { Focus on individual body parts } \\
\text { rather than holistic health }\end{array}$ & $\begin{array}{l}\text { "These poses not only tone and firm the glutes, they } \\
\text { also lengthen the buttocks and teach them to relax, } \\
\text { giving you a true "yoga butt." (Yoga Journal, 2016) }\end{array}$ \\
\hline & $\begin{array}{l}\text { Bodies as acquirable } \\
\text { commodities }\end{array}$ & $\begin{array}{l}\text { "Madonna and Sting in the mid-1990s were role } \\
\text { models, an alpha male and an alpha female who go } \\
\text { 'I'm not afraid to do yoga' and they're the most } \\
\text { sexy, successful, made-it kind of people, } \\
\text { demystifying something that is an ancient spiritual } \\
\text { practice." (Interview with veteran yoga entrepreneur } \\
\text { and instructor). }\end{array}$ \\
\hline & Body as identity & $\begin{array}{l}\text { October } 2002 \text { Vogue cover and cover story: "Your } \\
\text { best shape ever: How yoga can change your body } \\
\text { and your life" }\end{array}$ \\
\hline \multirow[t]{2}{*}{ Templates } & Franchising & $\begin{array}{l}\text { "Why not? What's wrong with [the McYoga } \\
\text { franchising model]? I eat Big Mac ... It's getting } \\
\text { more popular, spreading out all over like } \\
\text { McDonald's" (Bikram Chaudhry in Brezinski, } \\
\text { 2005). }\end{array}$ \\
\hline & Certification & $\begin{array}{l}\text { "We never thought there could be diplomas and } \\
\text { certificates for yoga instructors. They were gurus } \\
\text { after all. Sadly, today, it is not different from any } \\
\text { industry." (Interview with Yoga Journal Editor) }\end{array}$ \\
\hline
\end{tabular}




\section{APPENDIX A}

Illustration of overlap between yoga and New Age movements: A typical ad for New Age Journal that appeared in Yoga Journal

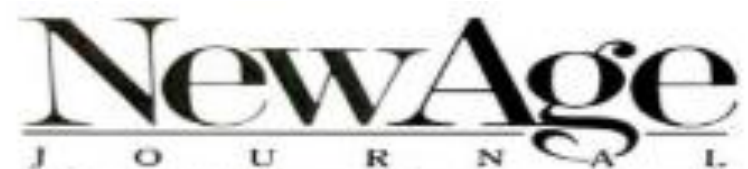

is for people like you who are searching for alternative ways to achieve a satisfying balance in life. A mageasine that helps you take charge of your life and your health.

It explores the connection between bocly and mind, individual and community. humanity and nature.

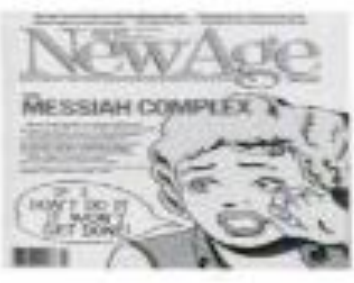
You'll find creative new approaches to relationships, forod, health, politics,

business, rechnology, and the environment.

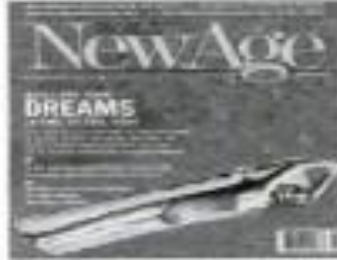

$$
\text { It's committed }
$$

to helping you

achieve your personal groals - and, at the same time, looks beyond those private interests to the world arcound you. Bouh for and

our society. New Aret Jounar. platces you at the leading edge of contemporary social opinion. 